\title{
The immunomodulatory effects of endocrine therapy in breast cancer
}

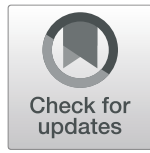

Huanhuan Huang ${ }^{1,2+}$, Jun Zhou ${ }^{3 \dagger}$, Hailong Chen ${ }^{1 \dagger}$, Jiaxin $\mathrm{Li}^{1,2}$, Chao Zhang ${ }^{4}$, Xia Jiang ${ }^{5,6^{*}}$ and Chao Ni ${ }^{1,2^{*}}$

\begin{abstract}
Endocrine therapies with SERMs (selective estrogen receptor modulators) or SERDs (selective estrogen receptor downregulators) are standard therapies for patients with estrogen receptor (ER)-positive breast cancer. Multiple small molecule inhibitors targeting the PI3K-AKT-mTOR pathway or CDK4/6 have been developed to be used in combination with anti-estrogen drugs to overcome endocrine resistance. In addition to their direct antitumor effects, accumulating evidence has revealed the tumor immune microenvironment (TIM)-modulating effects of these therapeutic strategies, which have not been properly acknowledged previously. The immune

microenvironment of breast tumors plays a crucial role in tumor development, metastasis and treatment response to endocrine therapy and immunotherapy. Therefore, in our current work, we comprehensively review the immunomodulatory effect of endocrine therapy and discuss its potential applications in combination with immune checkpoint inhibitors in breast cancer treatment.
\end{abstract}

Keywords: Breast cancer, Endocrine therapy, PI3K-AKT-mTOR pathway, CDK4/6, Tumor immune microenvironment

\section{Background}

Breast cancer $(\mathrm{BC})$ remains the most common malignant tumor threatening women's health worldwide [1]. As more than $75 \%$ of the diagnosed cases express estrogen receptor alpha $(E R \alpha)$ [2], it has been considered the most important target of endocrine therapies. Since tamoxifen was first discovered for its antitumor function in $\mathrm{BC}$, several anti-estrogen regimens, including SERMs (selective estrogen receptor modulators), SERDs (selective estrogen receptor downregulators), AIs (aromatase inhibitors) and GnRHa (gonadotropin-releasing hormone antagonists), have been developed to improve patient outcomes [3], yet endocrine resistance and disease progression still occurs in approximately $50 \%$ of these patients [4]. Activation of PI3KCA-AKT-mTOR pathway is known as the most important and prevalent

\footnotetext{
* Correspondence: xia.jiang@ki.se; nicaho428@zju.edu.cn

${ }^{5}$ School of Public Health and West China Fourth Hospital, Sichuan University, Chengdu, Sichuan 610064, China

'Department of Breast Surgery, Second Affiliated Hospital Zhejiang University, Zhejiang 310009 Hangzhou, China

Full list of author information is available at the end of the article
}

mechanism of endocrine resistance in $\mathrm{BC}$, as clinical trials have confirmed the definite efficacy of drugs targeting PI3KCA, AKT or mTOR [5-7]. Moreover, regimens targeting the cell cycle regulatory protein CDK4/6 in combination with anti-estrogen regimens (SERDs/AIs) have also been demonstrated to greatly improve the prognosis of $\mathrm{ER} \alpha+\mathrm{BC}[8,9]$. In addition to the direct antitumor effect of these endocrine therapies and small molecular inhibitors, increasing lines of evidence has highlighted a complex interplay between them and the tumor immune microenvironment (TIM), which is mainly composed of $\mathrm{T}$ cells, B cells, dendritic cells, macrophages, neutrophils, etc.. This interplay further affects tumor progression and endocrine resistance in $\mathrm{BC}[10$ 12]. However, the immune modulatory effect of the above indicated anti-estrogen regimens and small molecule inhibitors has rarely been systematically discussed. Therefore, we aim to provide a comprehensive review on the impact of various endocrine therapeutic strategies on the TIM in BC covering SERDs, SERMs, AIs, GnRHa and inhibitors of PI3K, AKT, mTOR and CDK4/6.

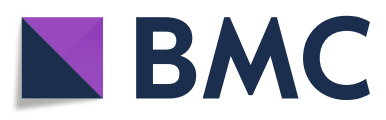

(c) The Author(s). 2021 Open Access This article is licensed under a Creative Commons Attribution 4.0 International License, which permits use, sharing, adaptation, distribution and reproduction in any medium or format, as long as you give appropriate credit to the original author(s) and the source, provide a link to the Creative Commons licence, and indicate if changes were made. The images or other third party material in this article are included in the article's Creative Commons licence, unless indicated otherwise in a credit line to the material. If material is not included in the article's Creative Commons licence and your intended use is not permitted by statutory regulation or exceeds the permitted use, you will need to obtain permission directly from the copyright holder. To view a copy of this licence, visit http://creativecommons.org/licenses/by/4.0/ The Creative Commons Public Domain Dedication waiver (http://creativecommons.org/publicdomain/zero/1.0/) applies to the data made available in this article, unless otherwise stated in a credit line to the data. 


\section{The effects of estrogen on the immune system}

Estrogen, an aromatized steroid hormone produced mainly in gonads and extraglandular tissues, participates in a wide range of physiological processes through the ER signaling pathway. Although the production of estrogen by ovaries ceases among postmenopausal women, estrogen is continually generated by the adipose tissue [13], of which both normal and tumor-bearing breasts are enriched. It has been estimated that the level of estradiol in breast tumor is 50-100 fold higher than that in normal breast tissue or in circulation, indicating an in situ synthesis capacity of breast tumor cells [14]. Indeed, acquired CYP19A1 (encoding aromatase) amplification in $\mathrm{BC}$ cells has been found in $21.5 \%$ of relapsed AItreated patients, and this alteration causes autonomous estrogen biosynthesis that activates ER $\alpha$ [15]. Moreover, the extensive expression of $E R \alpha / \beta$ in immune cells further supports the abnormal regulatory action of estrogen on immune system elements involving their development and functional responses [16].

Multiple studies have highlighted a pleiotropic effect of estrogen on immune cells involving polarization, cytokines production, proliferation and effector function. Macrophages, as part of the innate immune system, are one of the predominant infiltrating immune cells associated with breast tumor progression [17]. Estrogen can preferentially induce alternative activated (M2) macrophages which usually sustain tumor progression [18]. Multiple cytokines produced by functional macrophages, including matrix metalloproteinase-9 (MMP-9), IL-6, TNF $\alpha$ and IL-1 $\beta$, are dampened under the action of estrogen-ER $\alpha$ signaling [19-21], exerting both antitumor and protumor functions. Estrogen is known to directly or indirectly inhibit NK cell cytotoxic activity, the latter function of which depends on estrogen-induced production of the granzyme $\mathrm{B}$ inhibitor protease inhibitor 9 (PI-9) by target cells, including BC cells [22, 23]. Furthermore, the effect of estrogen on DCs varies at different stages. On the one hand, estrogen promotes the differentiation of DC progenitors and costimulatory molecule expression on differentiated conventional DCs [16, 24]. On the other hand, antigen presentation by mature DCs can be impaired after estrogen treatment, with decreased secretion of IFN $\gamma$, TNF $\alpha$ and IL-12 [25]. The increased production of indoleamine 2,3-dioxygenase (IDO) in DCs induced by estrogen reveals its suppressive function on antigen-specific $\mathrm{T}$ cells [26]. Estrogen has also been shown to directly inhibit the proliferation of CD4 + T cells as well as to reduce the expression of IL-2 and IL-2R [27]. In addition, estrogen also promotes the amplification and immunosuppressive capacity of regulatory T cells (Tregs) and myeloid-derived suppressor cells (MDSCs) [28, 29]. The expression of Foxp3 and programmed cell death 1 receptor (PD-1) responsible for the suppressive function of Tregs can be upregulated by estrogen in an ER $\alpha$-dependent manner [28, 30]. Estrogen further induces the infiltration and activation of neutrophils with an increased expression of protumoral cytokines and chemokines (e.g. S100A-8, S100A-9, CXCL-1, and CXCL-2), tissue-remodeling enzymes (MMP-3 and MMP-9) and COX-2 during mammary involution [31]. Protumoral neutrophils exacerbate the formation of tumor-promoting microenvironment, which further encourages BC progression [31, 32].

For a detailed description, please also read a review written by Segovia-Mendoza et al. [18] on the immune modulatory effect of estrogen in different immune cells. To summarize as illustrated in Fig. 1, estrogen acts as an immune-suppressive factor in favor of tumor emergence and progression. As such, along with its direct killing effect on cancer cells, anti-estrogen therapy may orchestrate an antitumor/pro-immune surveillance TIM in BC.

\section{The effects of SERMs and SERDs on the tumor immune microenvironment}

SERMs and SERDs are currently the most important endocrine therapeutic regimens for BC. SERMs, represented by tamoxifen, toremifene and raloxifene, work through competitive blockage of the interaction between estrogen and ER $\alpha$. SERDs, such as fulvestrant, contribute to the downregulation and degradation of ER $\alpha$ [33]. Accumulating evidence from experimental and clinical studies has revealed the multifaceted immunomodulatory effects of SERMs and SERDs [34]; in particular, progress has been made to elaborate how SERMs and SERDs act upon the immune microenvironment of BC (see Table 1).

In a mouse $\mathrm{BC}$ model with tamoxifen resistance, genes relevant to the immune system processing were found to be upregulated. Subsequent gene ontology analysis showed that a majority of upregulated genes were associated with interferon pathways, with interferon regulatory factor 7 (IRF-7) identified as a key regulator of the downstream IFN-dependent immune responses linked to tamoxifen resistance [78]. An immune-polarizing side effect (IPSE) of tamoxifen has also been reported. Tamoxifen induced a shift of mouse myelin-specific CD4 + T cells from a TH1 phenotype targeted against tumor cells towards a TH2 phenotype, indicating its damaging effect on antitumor immunity $[34,79]$. Consistent with experimental data, patients with low tumor-induced TH2 polarization status before treatment showed better prognosis due to their better resistance against the IPSE of tamoxifen [80]. In addition, Joffroy et al. [12] found that tamoxifen- or fulvestrant-induced TGF $\beta$ production in MCF-7 cells led to a decreased cytotoxic effect of CD8 + $\mathrm{T}$ cells as well as an increased polarization of CD4 $+\mathrm{T}$ cells into Foxp3+Tregs, which futher supported the 


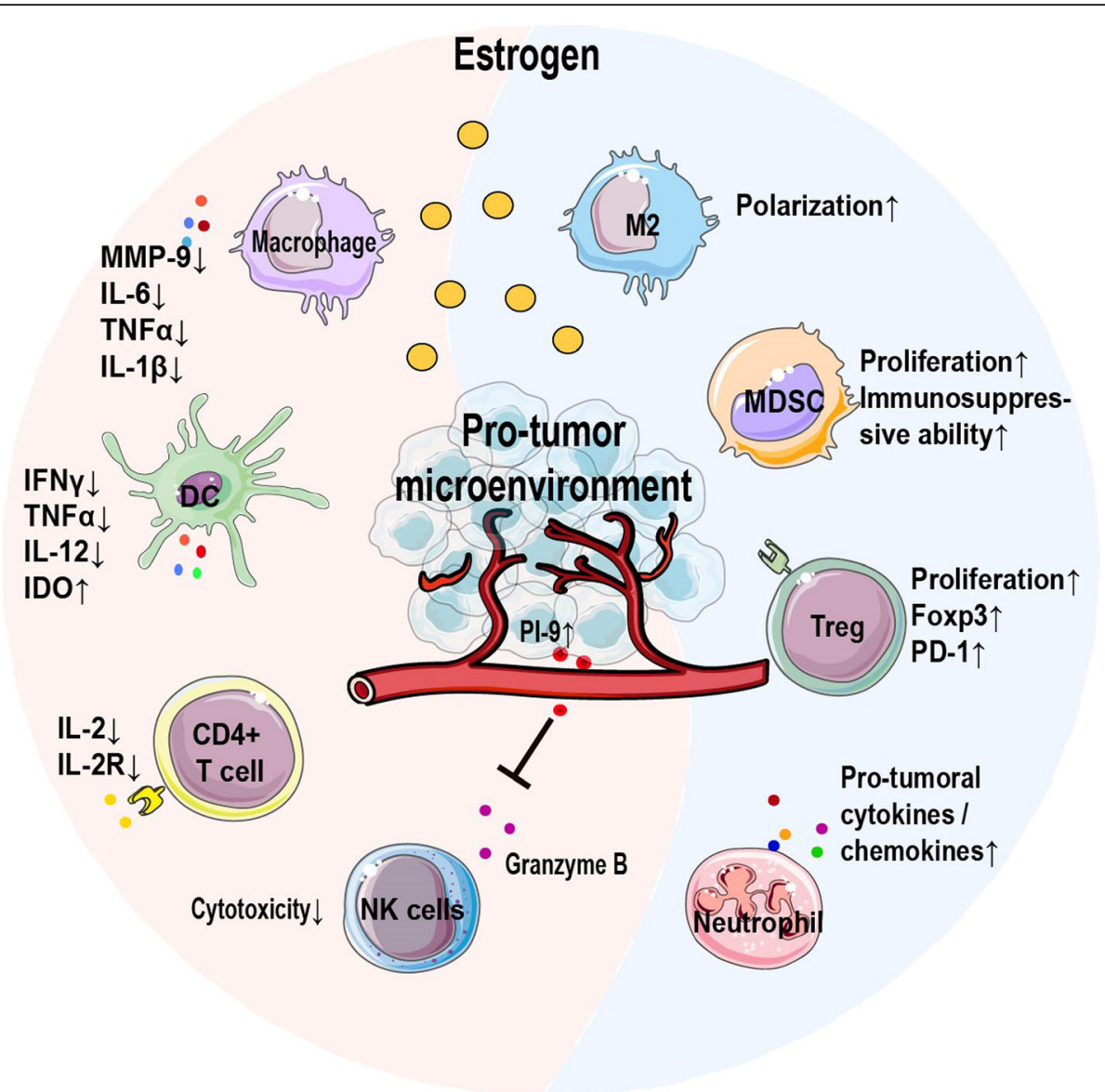

Fig. 1 Estrogen induces suppressive tumor immune microenvironment. Estrogen predominantly plays an immune-suppressive function in the TIM. Estrogen reduces multiple cytokines in macrophages and preferentially polarizes macrophages towards the M2 subtype. The infiltration of neutrophils with a protumoral signature may also be induced by estrogen. Both the proliferation and immunosuppressive function of Tregs and MDSCs can be potentiated by estrogen. Estrogen also inhibits the function of cytotoxic T cells, DCs and NK cells through multiple mechanisms

development of endocrine resistance. Moreover, ER $\alpha$ signaling blockade or depletion by tamoxifen or fulvestrant evoked the upregulation of programmed deathligand 1 (PD-L1) in multiple ER + BC cell lines, contributing to the cytotoxic $\mathrm{T}$ cell evasion of $\mathrm{BC}$ cells [81]. The inverse correlation between ER $\alpha$ and PD-L1 was confirmed not only in the MMTV-PyMT transgenic mouse model [81] but also in human BC specimens, where the ratio of PD-L1 positive patients was much lower in ER+/HER2- BC (19.4\%) than in triple-negative breast cancer (TNBC, 58.6\%) [82, 83]. To summarize, SERMs or SERDs mediate immunosuppressive effects in a direct or indirect manner and protect tumors from immune surveillance, which may decrease their therapeutic effects and result in the development of treatment resistance.

On the other hand, SERMs and SERDs have also been found to enhance the immunogenicity of $\mathrm{BC}$ and improve the antitumor immunity. The lactation protein $\alpha$ lactalbumin, known as an immunotherapeutic target of breast tumor treatment, is usually downregulated during cancer development. Jaini et al. found tamoxifen and fulvestrant effectively promoted $\alpha$-lactalbumin expression in $\mathrm{BC}$ cells while leaving the normal breast tissue unaffected, resulting in enhanced breast tumor inhibition via targeted immune therapy [84]. Furthermore, the cytotoxicity of NK cells was also found to be boosted by tamoxifen, which upregulated c-erbB-2 expression in HER2/neu nonamplified BC and led to tumor cell lysis by NK cell-mediated antibody-dependent cytotoxicity (ADCC). Interestingly, in cells presenting HER2/neu amplification, although tamoxifen upregulated HER2/ neu, it failed to improve sensitivity to the cytotoxic effect of NK cells. This may be explained by a ceiling effect induced by the limited Fc receptors on NK cells [36]. Similar to tamoxifen, toremifene upregulates intercellular adhesion molecule-1 (ICAM-1) expression on MCF-7 cells, and ICAM-1 is a key factor bridging and forming the immunological synapses between NK and target cells [85]. Moreover, estrogen-induced tumor immune 
Table 1 The effects of different endocrine therapeutic strategies on immune cells

\begin{tabular}{|c|c|c|c|c|}
\hline Therapeutic strategy & Subdivision & Drug/inhibitor & $\begin{array}{l}\text { Modulate TIM } \\
\text { component }\end{array}$ & Effects on immune cells \\
\hline \multirow[t]{14}{*}{ Anti-estrogenic drugs } & \multirow{5}{*}{$\begin{array}{l}\text { Selective estrogen receptor } \\
\text { Modulators (SERMs) }\end{array}$} & \multirow{5}{*}{$\begin{array}{l}\text { tamoxifen, toremifene, } \\
\text { raloxifene }\end{array}$} & CD8+T cells & proliferation $\uparrow[35]$, cytotoxicity $\downarrow[12]$ \\
\hline & & & CD4+T cells & Treg polarization $\uparrow[12]$ \\
\hline & & & NK cells & cytotoxicity $\uparrow[36]$ \\
\hline & & & DCs & $\begin{array}{l}\text { functional differentiation and immunostimulatory } \\
\text { capacity } \downarrow[37]\end{array}$ \\
\hline & & & neutrophils & $\begin{array}{l}\text { tamoxifen improves the proinflammatory pathway } \\
\text { [38], while raloxifene has the opposite effect [39] }\end{array}$ \\
\hline & \multirow{4}{*}{$\begin{array}{l}\text { Selective estrogen receptor } \\
\text { down-regulators (SERDs) }\end{array}$} & \multirow[t]{4}{*}{ fulvestrant } & CD8+T cells & cytotoxicity $\downarrow[12]$, tumor infiltration $\uparrow[40]$ \\
\hline & & & CD4+T cells & Treg polarization $\uparrow[12]$, tumor infiltration $\uparrow[40]$ \\
\hline & & & MDSCs, Tregs & tumor infiltration $\downarrow[40]$ \\
\hline & & & DCs & tumor infiltration $\uparrow[40]$ \\
\hline & \multirow[t]{4}{*}{ Aromatase inhibitors (Als) } & \multirow{4}{*}{$\begin{array}{l}\text { letrozole, anastrozole, } \\
\text { exemestane, } \\
\text { formestane }\end{array}$} & CD8+T cells & tumor infiltration $\uparrow[41]$ \\
\hline & & & CD4+T cells & Treg polarization $\downarrow[42]$ \\
\hline & & & Tregs & $\begin{array}{l}\text { ERß inactivation induces immunosuppressive } \\
\text { activity } \downarrow[43]\end{array}$ \\
\hline & & & mast cells & ERß inactivation induces CCL-2 production $\downarrow$ [44] \\
\hline & $\begin{array}{l}\text { Gonadotropin-releasing } \\
\text { hormone antagonists } \\
\text { (GnRHa) }\end{array}$ & $\begin{array}{l}\text { Goserelin } \\
\text { triptorelin }\end{array}$ & T cells & induce $\mathrm{TH} 1$ shift [45] \\
\hline \multirow[t]{22}{*}{$\begin{array}{l}\text { Inhibition of the PI3K- } \\
\text { AKT-mTOR pathway }\end{array}$} & \multirow[t]{17}{*}{ PI3K inhibitors } & \multirow[t]{4}{*}{ pan-PI3K inhibitor } & macrophages & $\begin{array}{l}\text { proinflammatory cytokines production and motility } \downarrow \\
\text { [46] }\end{array}$ \\
\hline & & & Tregs & proliferation $\downarrow[47]$ \\
\hline & & & T cells & $\begin{array}{l}\text { cytokines and granzyme B secretion } \downarrow[48] \text {, tumor } \\
\text { infiltration } \uparrow[49]\end{array}$ \\
\hline & & & NK and B cells & tumor infiltration $\uparrow[49]$ \\
\hline & & \multirow[t]{3}{*}{ p110a inhibitor } & CD8+ T cells & $\begin{array}{l}\text { tumor infiltration } \uparrow[50] \text {, cytokines production and } \\
\text { cytotoxicity } \uparrow[51] \text {, }\end{array}$ \\
\hline & & & CD4+ T cells & cytokines production $\uparrow[51]$, Treg polarization $\downarrow$ [51] \\
\hline & & & MDSCs & tumor infiltration $\downarrow[52]$ \\
\hline & & \multirow[t]{2}{*}{ p110ß inhibitor } & macrophages & phagocytosis $\downarrow[53]$ \\
\hline & & & neutrophils & cell adhesion, spreading and ROS formation $\downarrow$ [54] \\
\hline & & \multirow[t]{4}{*}{ p110y inhibitor } & myeloid cells & tumor infiltration $\downarrow[55]$ \\
\hline & & & macrophages & M1 polarization $\uparrow[56]$ \\
\hline & & & CD8+T cells & $\begin{array}{l}\text { PD-1 and CTLA-4 expression } \uparrow \text { [57], tumor infiltra- } \\
\text { tion } \uparrow[49]\end{array}$ \\
\hline & & & $\begin{array}{l}\text { CD4+Tcells, B } \\
\text { cells }\end{array}$ & tumor infiltration $\uparrow[49]$ \\
\hline & & \multirow[t]{4}{*}{ p1108 inhibitor } & macrophages & tumor infiltration $\downarrow[58]$ \\
\hline & & & MDSCs, Tregs & immunosuppressive function $\downarrow[59]$ \\
\hline & & & T cells & effector response of effector/memory T cells $\downarrow$ [60] \\
\hline & & & B cells & proliferation, survival and differentiation $\downarrow[61]$ \\
\hline & \multirow[t]{3}{*}{ AKT inhibitors } & \multirow[t]{3}{*}{ capivasertib } & Tregs & proliferation $\downarrow[47]$ \\
\hline & & & MDSCs & differentiation and viability $\downarrow$ [62] \\
\hline & & & macrophages & $\begin{array}{l}\text { AKT1 ablation } \rightarrow \mathrm{M} 1 \text { phenotype, AKT2 ablation } \\
\rightarrow \mathrm{M} 2 \text { phenotype }[63]\end{array}$ \\
\hline & \multirow[t]{2}{*}{ mTOR inhibitors } & \multirow[t]{2}{*}{ rapamycin, everolimus } & $\begin{array}{l}\text { mononuclear } \\
\text { cells }\end{array}$ & polarization towards M1 macrophage \\
\hline & & & macrophages & proinflammatory cytokine production and motility $\downarrow$ \\
\hline
\end{tabular}


Table 1 The effects of different endocrine therapeutic strategies on immune cells (Continued)

\begin{tabular}{|c|c|c|c|c|}
\hline Therapeutic strategy & Subdivision & Drug/inhibitor & $\begin{array}{l}\text { Modulate TIM } \\
\text { component }\end{array}$ & Effects on immune cells \\
\hline & & & & {$[46]$} \\
\hline & & & NK cells & proliferation and cytotoxicity $\downarrow[64,65]$ \\
\hline & & & DCs & 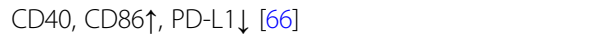 \\
\hline & & & CD8+ T cells & $\begin{array}{l}\text { anergic state induction }[67,68] \text {, tumor infiltration } \downarrow \\
{[69]}\end{array}$ \\
\hline & & & CD4+ T cells & $\begin{array}{l}\text { induce Tregs polarization and Foxp3 stable } \\
\text { expression [70] }\end{array}$ \\
\hline & & & үऽT cells & $\begin{array}{l}\text { cytotoxicity of } \bigvee \gamma 4 \gamma \delta T \text { cells } \uparrow[71] \text {, proliferation and } \\
\text { cytotoxicity of } \bigvee \gamma 2 \vee \delta 2 T \text { cells } \uparrow a n d \text { apoptosis } \downarrow[72]\end{array}$ \\
\hline & & & Tregs & $\begin{array}{l}\text { transient mTOR inhibition: reverse the } \\
\text { hyporesponsiveness [73] } \\
\text { chronic mTOR inhibition: proliferation } \downarrow \text {, suppressive } \\
\text { function } \downarrow[73,74]\end{array}$ \\
\hline \multirow{4}{*}{$\begin{array}{l}\text { Inhibition of the cell } \\
\text { cycle }\end{array}$} & \multirow[t]{4}{*}{ CDK4/6 inhibitors } & \multirow{4}{*}{$\begin{array}{l}\text { abemaciclib, } \\
\text { palbociclib, ribociclib }\end{array}$} & myeloid cells & tumor infiltration $\downarrow[75]$ \\
\hline & & & $\begin{array}{l}\text { macrophages, } \\
\text { DCs }\end{array}$ & antigen presentation $\uparrow[76]$ \\
\hline & & & T cells & $\begin{array}{l}\text { PD-1 and CTLA-4 expression } \uparrow[52] \text {, activation } \uparrow, ~ I L-2 \\
\text { production } \uparrow[75]\end{array}$ \\
\hline & & & Tregs & inhibition of the cell cycle [77] \\
\hline
\end{tabular}

tolerance was revealed to be partially abolished by tamoxifen though suppression of FasL expression as well as blockade of cancer-derived CCL-2/CCL-5 [86, 87]. Intriguingly, SERDs (either fulvestrant or JD128), despite lacking a direct antitumor effect on ER-negative BC, were found to reduce the counts of MDSCs and Tregs as well as increase the infiltration of DCs and CD8 + and $\mathrm{CD} 4+\mathrm{T}$ cells in 4T1 tumor-bearing mice. These changes in immune cell subpopulations in the TIM elicited by SERDs significantly improved the efficiency of anti-PD-L1 therapy [40]. Beyond SERMs/SERDs-induced antitumor immunity, the upregulated expression of PDL1 on tumor cells also raises the potential of using antiestrogens in combination with immune checkpoint blockers (ICBs) in BC. A multitude of clinical trials (see Table 2) evaluating the efficiency of ICBs in combination with anti-estrogen therapy are ongoing and will release their findings in the near future.

In addition to being effective for treating $\mathrm{BC}$, tamoxifen and raloxifene have also been shown to reduce the risk of BC in highly susceptible women [88]. Tamoxifen administration was found to upregulate IFN-related genes in normal human mammary epithelial cells from in vitro experiments, implying its positive effect on the immune surveillance of normal breast tissue [89]. Moreover, tamoxifen and toremifene were also found to enhance TNF-R2 expression on activated $\mathrm{T}$ cells by inhibiting the activation of JNK and promoting TNF-R2mediated $\mathrm{T}$ cell proliferation [35]. These results might explain their BC-preventive effect.
In contrast, the functional differentiation and immunostimulatory capacity of DCs were affected by tamoxifen and raloxifene, which acted to maintain the immature state of DCs by depressing their response to inflammatory stimuli [37]. Neutrophils, the major effector immune cells in inflammation, were also affected by SERM treatment. Corriden et al. [38] revealed a positive effect of tamoxifen on the proinflammatory processes of human neutrophils, including chemotaxis, phagocytosis and ceramide/PKC $\zeta$-mediated neutrophil extracellular traps (NETs) formation. Nevertheless, the same group later found raloxifene exerted an inhibitory effect on ceramide expression in neutrophils and phorbol 12-myristate 13-acetate (PMA)-induced NETs, suppressing the NETs-based killing function of neutrophils against bacterial pathogens [39]. The distinct effects of tamoxifen and raloxifene on NETs formation in neutrophils might be due to their slight differences in molecular structure. Since the neutrophil accumulation and NETs formation induced by inflammation are the main processes awakening dormant tumor cells, which can remain quiescent for decades before relapse [90], it is worthwhile to evaluate the effect of tamoxifen and raloxifene on quiescent $\mathrm{BC}$ cells, such as cancer stem cells, in preclinical models of $\mathrm{BC}$.

\section{The effects of estrogen deprivation on the immune microenvironment}

Estrogen deprivation has been proved to be more effective in postmenopausal or high-risk premenopausal 
Table 2 Ongoing clinical trials of endocrine therapy combined with immune checkpoint inhibitors therapies for breast cancer

\begin{tabular}{|c|c|c|c|c|c|c|}
\hline Treatment arms & $\begin{array}{l}\text { Clinicaltrials.gov } \\
\text { identifier }\end{array}$ & Phase & Patient and enrollment criteria & $\begin{array}{l}\text { Primary Outcome } \\
\text { Measures }\end{array}$ & $\begin{array}{l}\text { Secondary } \\
\text { Outcome } \\
\text { Measures }\end{array}$ & $\begin{array}{l}\text { Completion } \\
\text { Date }\end{array}$ \\
\hline $\begin{array}{l}\text { Pembrolizumab + } \\
\text { Tamoxifen }\end{array}$ & NCT03879174 & 2 & $\begin{array}{l}\text { Advanced hormone receptor- } \\
\text { positive breast cancer and ESR1 } \\
\text { mutation }\end{array}$ & PFS, ORR & OS & $\begin{array}{l}\text { August 1, } \\
2022\end{array}$ \\
\hline $\begin{array}{l}\text { Pembrolizumab + } \\
\text { Fulvestrant }\end{array}$ & NCT03393845 & 2 & $\begin{array}{l}\text { Hormone receptor-positive, } \\
\text { HER2-negative advanced/meta- } \\
\text { static breast cancer }\end{array}$ & ORR & Safety profile & $\begin{array}{l}\text { January } 1 \\
2022\end{array}$ \\
\hline $\begin{array}{l}\text { Pembrolizumab + } \\
\text { Exemestane + Leuprolide }\end{array}$ & NCT02990845 & $1 / 2$ & $\begin{array}{l}\text { Premenopausal hormone } \\
\text { receptor positive/HER2 negative } \\
\text { locally advanced or metastatic } \\
\text { breast cancer }\end{array}$ & PFS & $\begin{array}{l}\text { AEs, ORR, CBR, } \\
\text { DOR }\end{array}$ & $\begin{array}{l}\text { December } \\
2021\end{array}$ \\
\hline $\begin{array}{l}\text { Durvalumab + Aromatase } \\
\text { Inhibitor (Anastrozole/ } \\
\text { Letrozole/Exemestane) }\end{array}$ & NCT03874325 & 2 & $\begin{array}{l}\text { Hormone receptor positive breast } \\
\text { cancer }\end{array}$ & $\begin{array}{l}\text { Rate of modified } \\
\text { preoperative } \\
\text { endocrine prognostic } \\
\text { index (mPEPI) score of } \\
0\end{array}$ & $C R, P R, P D, S D$ & $\begin{array}{l}\text { March 11, } \\
2025\end{array}$ \\
\hline $\begin{array}{l}\text { Atezolizumab + Fulvestrant, } \\
\text { Atezolizumab + Ipatasertib, } \\
\text { Atezolizumab + Ipatasertib } \\
+ \text { Fulvestrant }\end{array}$ & NCT03280563 & $1 / 2$ & $\begin{array}{l}\text { Hormone receptor positive, } \\
\text { human epidermal growth factor } \\
\text { receptor 2-negative breast cancer }\end{array}$ & OR & $\begin{array}{l}\text { PFS, CBR, OS, } \\
\text { DR, AEs }\end{array}$ & $\begin{array}{l}\text { October } 5 \\
2022\end{array}$ \\
\hline $\begin{array}{l}\text { Pembrolizumab + Letrozole } \\
+ \text { Palbociclib }\end{array}$ & NCT02778685 & 2 & $\begin{array}{l}\text { Estrogen receptor positive, HER2/ } \\
\text { neu negative, postmenopausal } \\
\text { metastatic breast carcinoma, } \\
\text { stage IV breast cancer }\end{array}$ & $C R, P R$ & $\begin{array}{l}\text { CRR, DOR, AEs, } \\
\text { OS, PFS, TTF }\end{array}$ & $\begin{array}{l}\text { September } \\
2020^{\mathrm{a}}\end{array}$ \\
\hline $\begin{array}{l}\text { Fulvestrant + Palbociclib + } \\
\text { Avelumab }\end{array}$ & NCT03147287 & 2 & $\begin{array}{l}\text { Metastatic hormone receptor } \\
\text { positive, HER2 negative breast } \\
\text { cancer }\end{array}$ & PFS & ORR, AES & $\begin{array}{l}\text { December } \\
31,2024\end{array}$ \\
\hline $\begin{array}{l}\text { Abemaciclib + } \\
\text { Pembrolizumab, } \\
\text { Abemaciclib + } \\
\text { Pembrolizumab + } \\
\text { Anastrozole }\end{array}$ & NCT02779751 & $1 b$ & $\begin{array}{l}\text { Hormone receptor-positive, } \\
\text { HER2-negative breast cancer }\end{array}$ & SAEs, AEs & $\begin{array}{l}\text { ORR, DCR, DOR, } \\
\text { PFS, OS, PK }\end{array}$ & $\begin{array}{l}\text { October 29, } \\
2021\end{array}$ \\
\hline $\begin{array}{l}\text { Abemaciclib + Durvalumab } \\
+ \text { Aromatase inhibitor } \\
\text { (exemestane/anastrozole/ } \\
\text { letrozole) }\end{array}$ & NCT04088032 & 1 & $\begin{array}{l}\text { Locally advanced hormone } \\
\text { receptor-positive breast cancer }\end{array}$ & AEs & $\begin{array}{l}\text { Pathologic } \\
\text { response at } \\
\text { surgery }\end{array}$ & $\begin{array}{l}\text { December } \\
31,2020\end{array}$ \\
\hline $\begin{array}{l}\text { Nivolumab + Palbociclib + } \\
\text { Anastrozole }\end{array}$ & NCT04075604 & 2 & $\begin{array}{l}\text { Hormone receptor positive, } \\
\text { HER2-negative breast cancer }\end{array}$ & $\mathrm{DLT}, \mathrm{RCB}$ & $\begin{array}{l}\text { AEs, SAE, } \\
\text { laboratory } \\
\text { abnormalities, } \\
\text { pCR, ORR, BCS } \\
\text { rate }\end{array}$ & $\begin{array}{l}\text { March 9, } \\
2022\end{array}$ \\
\hline
\end{tabular}

Abbreviations: PFS Progression Free Survival, ORR Overall Response Rate, OS Overall Survival, AEs Adverse Events, CBR Clinical Benefit Rate, DOR Duration of Overall Response, $C R$ Complete Response, $P R$ Partial Response, PD Progression of Disease, SD Stable Disease, OR Objective Response, $D R$ Duration of Response, CRR Complete Response Rate, TTF Time to treatment failure, SAEs Serious Adverse Events, DCR Disease Control Rate, PK Pharmacokinetics, $p C R$ Pathological Complete Response, $B C S$ Breast Conserving Surgery

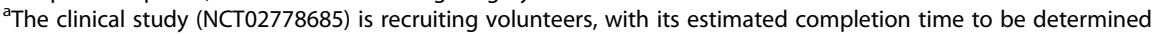

patients treated with either aromatase inhibitors (AIs) alone or AIs combined with a GnRHa (e.g., goserelin and triptorelin) than in other premenopausal women [91]. AIs could be classified into steroid (letrozole and anastrozole) and nonsteroid (exemestane and formestane) subtypes. Although the two subtypes interact with aromatase in different manners, their clinical efficacies are similar [92]. In contrast to SERMs and SERDs, estrogen deprivation leads to suppression of both ER $\alpha$ and ER $\beta$ signaling in target cells and affects immune regulation (see Table 1). Compared with ER $\alpha$, ER $\beta$ is more dominantly expressed on immune cells, especially under inflammatory and hypoxic conditions [93], which may contribute differentially to the TIM under estrogen deprivation and SERMs/SERDs treatment (depicted in Fig. 2).

Multiple studies have demonstrated that AIs and/or GnRHa promote an antitumor TIM. For example, formestane treatment made ER + tumors more sensitive to ADCC by monocytes, suggesting a positive effect of AIs on antigen-specific antitumor immunity [94]. TH1 polarization in the $\mathrm{T}$ cell population was also induced by 
GnRHa, increasing the TNF $\alpha+/ \mathrm{IL}-10+\mathrm{TH}$ cell ratio [45]. In addition, Generali et al. and Chan et al. evaluated the changes in TIL subtypes in $\mathrm{ER}+\mathrm{BC}$ patients before and after letrozole/exemestane treatment and found a reduction in Foxp3 $+\mathrm{T}$ cells and an increase in CD8 + $\mathrm{T}$ cell infiltration among AI responders $[41,95]$. The abrogation of estrogen-induced Treg proliferation and immunosuppressive activity may be responsible for the increased CD8+/Treg ratio after AI treatment. Moreover, anastrozole administration in rat models inhibited the differentiation of naive CD $4+\mathrm{T}$ cells into Tregs and reduced Treg counts in spleens and popliteal lymph nodes [42]. Additionally, recent studies revealed the importance of ER $\beta$ activation in the induction, maintenance and immunosuppressive activity of Foxp3 + Tregs $[43,96]$. In this regard, estrogen withdrawal may be more effective in elevating the CD8+/Treg ratio in the TIM than SERMs or SERDs. Mast cells, as unique tissue-resident immune cells, are also involved in BC progression [97]. Rao et al. found that infiltrated mast cells within bladder cancer expressed higher levels of ER $\beta$ than non-infiltrated mast cells and further promoted tumor metastasis by enhancing ER $\beta / C C L-2 / C C R-$ 2/EMT/MMP-9 signaling in the TIM [44]. It is therefore reasonable to assume that the estrogen deprivationelicited inhibition of ER $\beta$ signaling prevents the role of mast cells in promoting tumor invasion by decreasing CCL-2 expression. In summary, compared to SERMs and SERDs, estrogen deprivation by AIs or GnRHa abrogates both ER $\alpha$ and ER $\beta$ signaling in tumor and immune cells, exerting a strong effect in reshaping the TIM.

The association between the TIM and endocrine therapy response has been evaluated. Bioinformatic analyses based on gene expression data revealed a lower infiltration of M1 macrophages and a higher infiltration of Tregs and M2 macrophages within ER + tumors than ER-negative tumors, as well as an enrichment of anergic $\mathrm{T}$ cells in anastrozole-irresponsive $\mathrm{ER}+\mathrm{BC}$ patients [98, 99]. Two studies implied that BC patients with high TIL numbers and baseline expression of immune-related genes, a subtype acknowledged to benefit from chemotherapy, responded poorly to anastrozole [100, 101]. Additionally, biomarker analysis of data from two clinical trials has evaluated the association between the TIM and neoadjuvant endocrine therapy (NET), yet different conclusions were drawn. The CARMINA-02 trial assessed 86 pre- and post-NET tumor samples, from patients treated with either anastrozole or fulvestrant, and found greatly increased TIL numbers in post-NET samples of responders but not in those of nonresponders [102]. In contrast, the DBCG trial revealed significantly increased TIL numbers in BC patients with poor response, who received letrozole as NET [103]. These discrepancies may be attributable to the different regimens used, suggesting the need for studies with more samples and corresponding pathological assessment. In addition, $E R+B C$ cells grown under estrogen-free conditions presented an upregulation of PD-L1 as a result of ER $\alpha$ signaling abrogation [81], corroborating the possibility of combining NET with immunotherapy in $\mathrm{ER}+\mathrm{BC}$.

\section{The effects of inhibiting PI3K-AKT-mTOR pathway on the immune microenvironment}

PI3K-AKT-mTOR signaling is the most common aberrantly activated pathway in $\mathrm{ER}+\mathrm{BC}$, and this aberrant signaling has been acknowledged as the main cause of endocrine resistance [104]. Various targeted drugs for inhibiting this pathway have been developed to reverse endocrine resistance and have shown promising results [4]. In addition to staving tumor growth, inhibitors of this pathway also impact the functions of multiple immune cells (illustrated in Fig. 3). Therefore, the effects of these therapeutic strategies on the TIM deserve attention.

\section{PI3K inhibitors}

PI3K inhibitors for ER + BC include pan-class I PI3K inhibitors targeting the $\mathrm{p} 110 \alpha, \mathrm{p} 110 \beta, \mathrm{p} 110 \gamma$ and $\mathrm{p} 110 \delta$ isoforms (buparlisib and pictilisib), as well as selective PI3K p110 $\alpha$ inhibitors (alpelisib and taselisib) [4]. The results from the BELLE-2 study showed that the addition of buparlisib to fulvestrant prolonged progression-free survival (PFS) by 1.9 months among advanced ER $+\mathrm{BC}$ patients. However, the accompanying severe toxicity, including mental disorders, impaired liver function, hyperglycemia and rash, impeded its application [105]. Nevertheless, a nonsignificant improvement of PFS in $\mathrm{ER}+\mathrm{BC}$ with a combination of pictilisib and fulvestrant was reported by the FERGI trial, and limiting the dosage of pictilisib due to toxicity might reduce its efficacy [106]. In contrast, preliminary clinical results showed a favorable clinical benefit and safety profile with selective p110 $\alpha$ inhibitors plus fulvestrant $[107,108]$.

The four catalytic isoforms of class I PI3K are widely expressed across different cell types in mammals, while $\mathrm{p} 110 \mathrm{\gamma}$ and $\mathrm{p} 110 \delta$ are mainly expressed in leukocytes [109]. Numerous in vivo and in vitro studies have revealed the immunomodulatory effects of multiple types of PI3K inhibitors (see Table 1). Xie et al. reported that the pan-PI3K inhibitor LY blocked the production of proinflammatory cytokines from macrophages including IL-1 $\beta$, IL-6, IL- 8 and TNF $\alpha$, and undermined macrophage motility [46]. Multiple pan-PI3K inhibitors caused impaired $\mathrm{T}$ cell function, as represented by decreased secretion of global cytokines and granzyme $\mathrm{B}$, due to the inactivation of p110 isoforms $\beta, \gamma$ and $\delta[48,110]$. These results suggest that the usage of pan-PI3K inhibitors may impair normal immune surveillance. On the other 


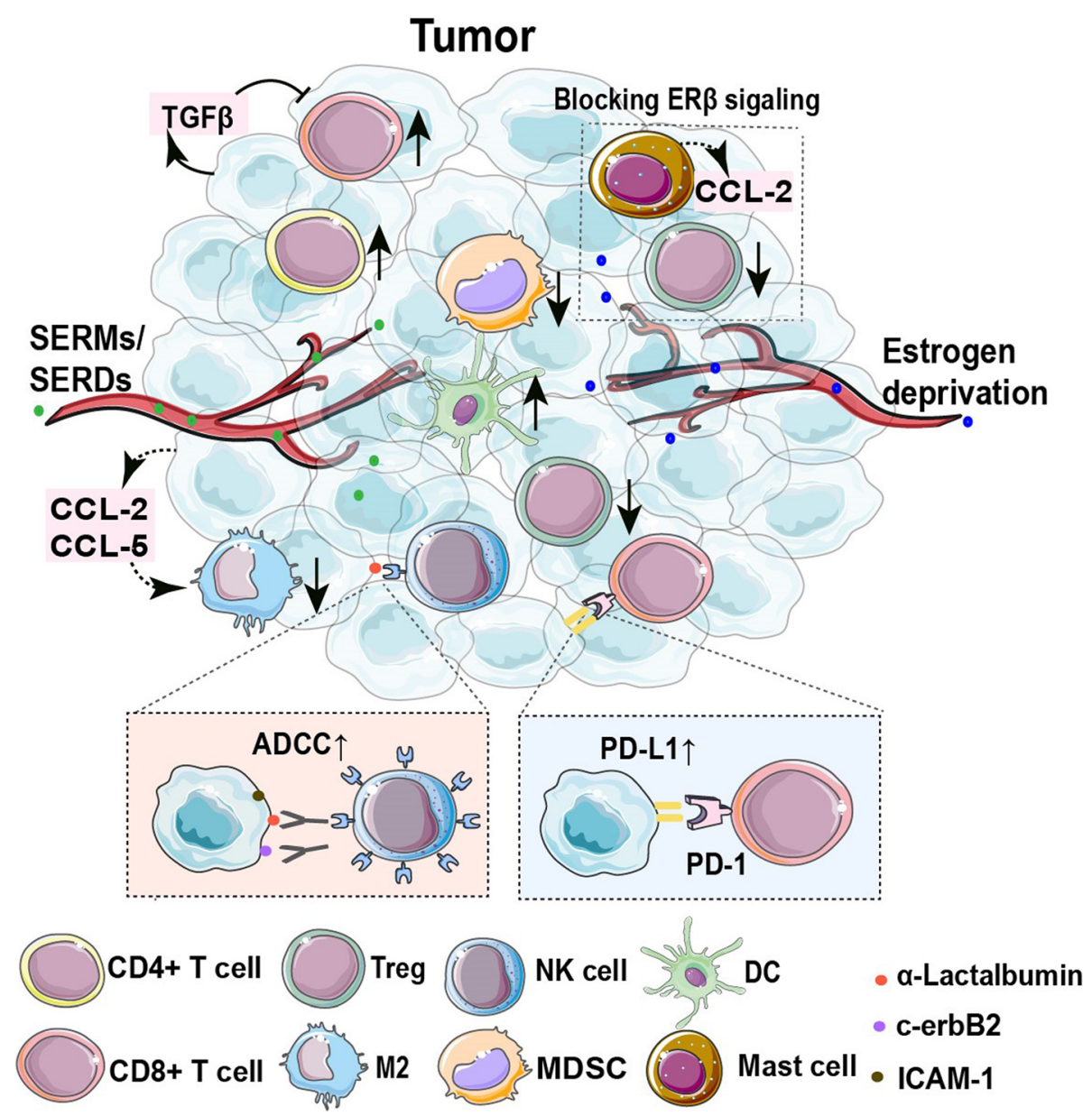

Fig. 2 Antiestrogen regimens participate in reshaping tumor immune microenvironment. Blocking or downregulating ERa with SERMs/SERDs and estrogen deprivation can enhance PD-L1 expression and immunogenicity of BC, as well as regulate multiple factors secreted by BC cells, such as TGF $\beta, C C L-2$ and CCL-5, indirectly modulating the tumor immune microenvironment. Enhanced NK cell-mediated antibody-dependent

cytotoxicity (ADCC) increased the infiltration of CD4+ T cells, CD8+ T cells, and DCs and decreased the counts of Tregs and MDSCs within tumors can be found after anti-estrogen regimens treatment. Estrogen deprivation can lead to a greater inhibition of Tregs infiltration in tumor and block the production of CCL-2 by mast cells due to simultaneous suppression of ER $\beta$ signaling

hand, in vivo and in vitro investigations suggested that selective inhibition of Treg proliferation and maintenance by pan-PI3K inhibitors was capable of enhancing the $\mathrm{T}$ cell response [47]. Treatment with the pan-PI3K inhibitor BKM120 in mice bearing breast tumors was found to increase the tumor infiltration of NK cells, B cells, and CD4 + and CD8 + T cells, favoring antitumor immunity [49]. Furthermore, an early study found a higher level of PD-L1 expression in breast tumor specimens with PIK3CA mutation or PTEN loss than in those with wild-type versions of these genes, and the pan-PI3K inhibitor wortmannin could attenuate PD-L1-elicited immunosuppression by blocking S6K1-mediated transcription of PD-L1 in BC cells with activated PI3K [111]. Considering the complex immunomodulatory effects of pan-PI3K inhibitors, the application of selective isoform inhibitors might be able to simultaneously eradicate tumor cells and avoid the immunosuppressive effects of pan-PI3K inhibitors.

$\mathrm{p} 110 \alpha$ is emphasized as a key therapeutic target for $\mathrm{ER}+\mathrm{BC}$ due to the high mutation frequency of its gene, PIK3CA (34.5\%) [104]. The synergistic effect between a p110 $\alpha$-selective inhibitor and trastuzumab was reported in HER2 + BC mouse models [50]. Compared with a pan-PI3K inhibitor, the p110 $\alpha$-selective inhibitor preserved AKT activation in CD8 + TILs and showed a more potent effect in combination with the anti-neu antibody to increase the infiltration of CD8 + TILs. This may be because the important functions of p110 $\gamma$ and p110 $\delta$ isoforms in $\mathrm{T}$ cells are suppressed by pan-PI3K inhibitors [50]. The importance of the p110 $\alpha$ subunit in the $\mathrm{T}$ cell-dependent immune response was also 


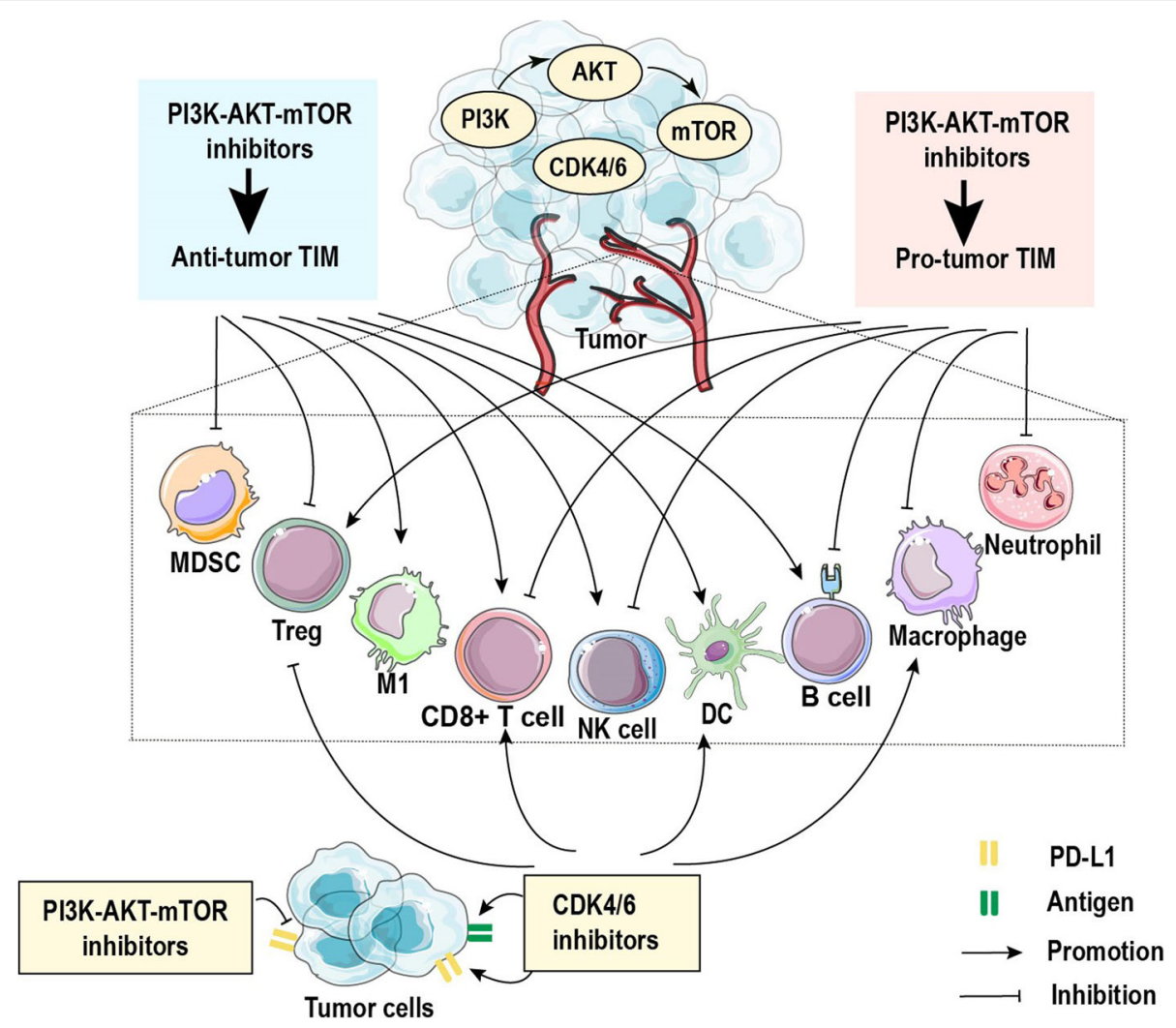

Fig. 3 PI3K-AKT-mTOR inhibitors and CDK4/6 inhibitors orchestrate multiple effects on immune cells in the tumor immune microenvironment. The blue frame represents the antitumor immunity induced by PI3K-AKT-mTOR inhibitors. p110a and mTOR inhibitors decrease the number of MDSCs in tumors. The immunosuppressive function of MDSCs can be limited by p110 $\delta$ and AKT inhibitors. p110 inhibitors and long-term inhibition of mTOR also weaken Treg function. Moreover, p110y and mTOR inhibitors promote the conversion of macrophages and mononuclear cells towards M1 phenotype. The function of CD8+ T cells is also enhanced by p110a, p110y and p1108 inhibitors. p110a inhibitors suppress CD4+ T cells polarization towards Tregs, while pan-PI3K and AKT inhibitors are capable of selectively suppressing Treg proliferation. Additionally, pan-PI3K and p110y inhibitors promote the tumor infiltration of T cells and B cells. Increased NK infiltration in tumors is also elicited by pan-PI3K inhibitors. Moreover, the function of DCs treated with mTOR inhibitors is significantly improved. The inhibition of PI3K-AKT-mTOR pathway also suppresses PD-L1 expression in BC cells, undermining PD-L1- mediated immunoresistance. The pink frame represents the protumor immunity induced by PI3K-AKT-mTOR inhibitors. pan-PI3K, p110 3 and mTOR inhibitors damage host defense mediated by macrophages, and p110 inhibition suppresses the cytotoxic function of neutrophils. p1108 inactivation shows an adverse effect on T cells and B cells. mTOR inhibitors can also suppress the effector function of T cells and NK cells, as well as promote Treg polarization. CDK4/6 inhibitors mainly induce antitumor immunity by improving the immunogenicity of BC cells and the antigen-presenting ability of DCs and macrophages. The CD $8+/ T r e g$ ratio is also increased within tumors after CDK4/6 inhibitor treatment. The elevated level of PD-L1 in BC cells and immune cells mediated by CDK4/6 inhibitors supports the combined usage of CDK4/6 inhibitors with immune checkpoint inhibitor

illuminated by Aragoneses-Fenoll et al. [51], who reported that $\mathrm{p} 110 \alpha^{-1-} \mathrm{CD} 4+$ and $\mathrm{CD} 8+\mathrm{T}$ cells elicited a potent effector function, including an increase in the production of cytokines, particularly IFN $\gamma$. In addition, elevated expression of lysosomal associated membrane protein 1 (LAMP-1) and granzyme B in $\mathrm{p} 110 \alpha^{-/-} \mathrm{CD} 8+$ $\mathrm{T}$ cells and diminished polarization of $\mathrm{p} 110 \alpha^{-/-} \mathrm{CD} 4+\mathrm{T}$ cells towards Tregs were also found. The p110 $\alpha$ deletion-induced improvement of antitumor immunity mediated by $\mathrm{T}$ cells delayed tumor progression in mice. Moreover, the p110 $\alpha$-selective inhibitor alpelisib combined with a CDK4/6 inhibitor was revealed to significantly improve tumor-infiltrating $\mathrm{CD} 4+$ and $\mathrm{CD} 8+\mathrm{T}$ cell activity and reduce the abundance of MDSCs in
TNBC mouse models [52].These findings strongly indicate a reshaping effect on the antitumor TIM induced by selective $\mathrm{p} 110 \alpha$ inhibitor, as well as their potential, together with ICBs, in cancer therapy.

The importance of $\mathrm{p} 110 \beta$ in the development and progression of BC has been investigated [112]. Studies with athymic nude mice found a better efficacy of dual p110 $\alpha / p 110 \beta$ inhibitors in ER $+B C$ than of single inhibitors $[113,114]$, yet others have indicated a negative effect of p110 $\beta$-specific inhibitors on immune cells. Leverrier et al. revealed that phagocytosis of mouse macrophages induced by apoptotic cells and Fc $\gamma \mathrm{R}$ can be depressed by anti-p110 $\beta$ antibodies, possibly due to the important role of $\mathrm{p} 110 \beta$ in $\mathrm{G}$ protein-coupled receptor 
and receptor tyrosine kinase signal transduction in macrophages [53]. p110 $\beta$ activity was required for neutrophil activation in response to adhesive surfaces and immune complexes. p110 $\beta$ inhibition could restrain the adhesion, spreading and ROS production of neutrophils, suppressing their phagocytic function [54]. Therefore, it is conceivable that pharmacological inhibition of p110 $\beta$ may counteract immune surveillance in BC.

In addition to the direct antitumor effect of selective p110y inhibitors, they may have a positive effect on antitumor immune surveillance. Studies reported the capacity of pharmacological inhibition of p110y in myeloid cells to restrict breast tumor inflammation and progression. Mechanistically, the activation of integrin $\alpha 4 \beta 1$ responsible for myeloid cell invasion into tumors was suppressed by p110 $\gamma$ inhibitor [55]. Selective inactivation of $\mathrm{p} 110 \mathrm{\gamma}$ also promoted polarization of macrophages towards a more inflammatory M1 phenotype by stimulating $\mathrm{NF}_{K} \mathrm{~B}$ activation and inhibiting $\mathrm{C} / \mathrm{EBP} \beta$ activation, leading to a restoration of $\mathrm{CD} 8+\mathrm{T}$ cell function [56, 57]. Moreover, $\mathrm{PI} 3 \mathrm{~K}^{-1-}$ mice with MMTV-PyMT tumors showed increased infiltration of antitumor leukocytes, including B cells and CD4 + and CD8 + T cells, into tumors, and these increased numbers of TILs with loss of $\mathrm{PI} 3 \mathrm{~K} \gamma$ contributed to the diminution of tumor growth [49]. These results suggest that p110y inhibition holds great potential to reshape the TIM. Intriguingly, the upregulated expression of PD-1 and CTLA- 4 on infiltrated CD8 + T cells was also found in 4T1 tumor with p110y inhibition [57]. Both p100y blockade-induced antitumor immunity and upregulation of immune checkpoint expression support the combined usage of p110 $\gamma$-selective inhibitor and ICBs, and the synergistic tumor-suppressing effects of such combinations have been demonstrated by multiple studies $[49,56,57]$.

Similar to other isoforms, p110 $\delta$ is widely expressed in leukocytes [109] and its expression level gradually increases as breast tumors progress [58]. A mouse model of TNBC under p110 $\delta$ inhibitor IC87114 treatment exhibited tumor growth retardation as a result of the direct p110 $\delta$ inactivation within tumor cells and macrophages accompanied by a reduction of tumor-infiltrating macrophages [58]. Moreover, administration of a p110 $\delta$ inhibitor in $4 \mathrm{~T} 1$ tumor-bearing mice undermined the function of Tregs and MDSCs, which disrupted tumor immune tolerance and further reignited CD8 + cytotoxic T cellmediated tumor clearance [59]. Considering the positive effect of estrogen on the proliferation and function of Tregs and MDSCs, p110 $\delta$ inhibitors may exhibit promising effects in ER $+\mathrm{BC}$. However, a large body of data has also shown an adverse effect of p110 $\delta$ on T cells and B cells, resulting in host immune deficiency. The p110 $\delta$ inhibitor IC87114 suppressed IFNY secretion by effector/ memory $\mathrm{T}$ cells in both human and mice, weakening their effector responses [60]. Significant impairment in the proliferation, survival and differentiation of B cells was observed after exposure to a selective p110 $\delta$ inhibitor [61]. Collectively, the dual effect of p110 $\delta$ on immune cells calls for rigorous and comprehensive studies in the future to evaluate the therapeutic value of $\mathrm{p} 110 \delta$ inhibitors in different malignant diseases and their impact on the TIM.

\section{AKT inhibitors}

Protein kinase B (AKT), a key target of the PI3K pathway, possesses three isoforms named AKT1, AKT2 and AKT3. Hyperactivation of AKT is prevalent in ER + BC and relevant to endocrine resistance [115]. The FAKT ION trial revealed that a pan-AKT inhibitor, capivasertib, improved PFS in AIs-resistant advanced $\mathrm{ER}+\mathrm{BC}$ patients [7].

Similar to pan-PI3K inhibitor, administration of an AKT inhibitor to PTEN-deficient BC cell lines exerted a suppressive effect on PD-L1 expression that could be upregulated by the activation of PI3K-AKT-mTOR pathway, reversing the immunosuppression elicited by PDL1 [111]. Selective depletion of Tregs within tumors was also induced by AKT inhibitors to further enhance antitumor immune responses and mitigate tumor growth [47]. Additionally, the importance of AKT in the differentiation of neoplastic MDSCs from myeloid precursors has been reported, and a specific AKT inhibitor hampered MDSC differentiation and viability [62]. However, the AKT1 and AKT2 isoforms play different roles in macrophage polarization. For example, AKT1 ablation in macrophages was reported to promote M1 phenotype polarization, which was attributed to its induction of miR-155 expression that targeted C/EBP $\beta$, a master regulator of M2 differentiation, while AKT2 deletion resulted in an M2 phenotype [63]. Reports also suggested that the activation of AKT2 induces macrophage chemotaxis and $\mathrm{BC}$ cells metastasis [116, 117]. In this regard, in addition to inhibiting tumor cells, AKT inhibitors may contribute to the formation of an antitumor immune microenvironment to some extent (see Table 1).

\section{mTOR inhibitors}

The mammalian target of rapamycin (mTOR), as a serine/threonine kinase in two complexes, mTORC1 and mTORC2, is a key regulators of cell growth, metabolism and autophagy. Everolimus, a rapamycin analog targeting mTORC1, has gained FDA approval for use in improving endocrine therapy resistance in advanced $E R+B C$ [118]. Considering the role of mTOR in immune cell differentiation and function [119], the changes in the immune microenvironment caused by mTOR inhibitors deserve attention (see Table 1). 
Indeed, increasing evidence has indicated the dual effects of mTOR inhibitors on the TIM. The secretion of IL- $1 \beta$, IL- 6, IL- 8 and TNF $\alpha$ by macrophages involved in macrophage motility and adhesion was depressed by mTOR inhibitor AZD, thereby suppressing macrophagemediated host defense [46]. mTOR signaling is also required for the development and activation of NK cells mediated by IL-15R signaling. mTOR inhibition with rapamycin led to impaired NK cell proliferation and reduced IFNY and granzyme B production [64, 65]. Additionally, the impact of mTOR inhibition on Tregs has been investigated. Everolimus facilitated TGF $\beta$ dependent Treg conversion from naive CD4 $+\mathrm{T}$ cells and Foxp3 stable expression by abating the activation of DNA methyl transferase 1 (DNMT-1) [70]. An anergic state of CD8 + T cells could also be induced by rapamycin: deficiency of mTORC1 activity among CD8 + T cells resulted in a low metabolic rate and increased longevity yet failed to differentiate memory $\mathrm{T}$ cells into effector cells, leading to a decreased cytotoxic function and anergic state. Meanwhile, inhibition of mTORC2 activity enhanced the generation of CD8 + memory T cells $[67,68$, 120]. In mice bearing lung tumors, rapamycin administration impaired the recruitment of CD8 $+\mathrm{T}$ cells into the tumor accompanied by the ability of the vaccine to reduce infiltration of Tregs and MDSCs [69]. These results reveal that mTOR inhibitors are beneficial for tumor to escape immune surveillance.

However, emerging evidence has also suggested the potential for mTOR inhibitors to impose an antitumor immune environment. Beyond suppressing the immunoresistance mediated by PD-L1 through a similar mechanism as wortmannin [111], rapamycin was found to polarize mononuclear cells towards M1 macrophages, a phenotype less sensitive to the apoptotic effect of rapamycin [121, 122]. Rapamycin administration also impeded mouse M-MDSC differentiation and immunosuppressive function by restraining glycolysis and the iNOS pathway to reactivate antitumor immunity [123, 124]. Although mTOR inhibition can directly impair the cytotoxicity and chemotaxis of CD $8+\mathrm{T}$ cells, myeloid DCs treated with rapamycin were found to have an increased expression of the costimulatory molecules CD40 and CD86 as well as a reduced expression of PD-L1, showing an enhanced ability to induce therapeutic CD8 + T cell responses [66, 125]. Rapamycin treatment also modulates the functional characteristics of $\gamma \delta \mathrm{T}$ cells, which are important in $\mathrm{BC}$ and have received great attention [126]. The cytotoxicity of $\mathrm{V} \gamma 4 \gamma \delta \mathrm{T}$ cells was significantly boosted by rapamycin through increased expression of NKG2D and TNFy [71]. In V $\mathrm{V}^{2} \mathrm{~V} \delta 2 \mathrm{~T}$ cells, mTOR inhibition led to an enhanced cytotoxicity and resistance to Fas-mediated apoptosis, as well as increased proliferation after antigen stimulation [72]. In addition, transient mTOR inhibition before TCR stimulation was revealed to reverse the hyporesponsiveness of Tregs, which was dependent on leptin-mTOR pathway, and promote the proliferation of functional Tregs [73]. However, chronic inhibition of mTOR eventually suppressed Treg expansion and even resulted in Treg anergy because the proliferation and suppressive ability of Tregs require high glycolytic metabolism, which is dependent of mTOR activity [73, 74]. These findings suggest a pleiotropic effect of mTOR inhibitors in BC, and implementing high-throughput techniques such as mass cytometry and single-cell RNA sequencing could provide more comprehensive data to evaluate the effect of such inhibitors on the TIM.

\section{The effects of CDK4/6 inhibitors on the immune microenvironment}

The cyclin D/cyclin-dependent kinases 4 and 6 (CDK4/ 6)-retinoblastoma protein (RB) pathway holds a core position in the development of BC. CDK4/6 inhibitors (CDK4/6i), including abemaciclib, palbociclib and ribociclib, in combination with hormone therapy have been used to treat hormone receptor-positive $(\mathrm{HR}+)$, HER2negative metastatic BC [127-129]. In addition to inducing tumor cell cycl e arrest, mounting evidence reveals the immune modulatory of CDK4/6i in the TIM of BC (depicted in Fig. 3 and Table 1).

CDK4/6i enhance the immunogenicity of BC cells through a variety of mechanisms. Abemaciclib and palbociclib boosted the production of type III IFNs of BC cells by abolishing the action of RB-E2F-DNMT1 axis, which further drove the expression of IFN-stimulated genes in an autocrine manner and enhanced tumor antigen presentation [77]. Abemaciclib monotherapy also upregulated the expression of MHC class I and II in tumor cells in favor of immune-mediated tumor clearance [76].

Administration of CDK4/6i inflames the TIM of BC by reversing "cold" tumors to "hot" tumor by repressing immunosuppressive cells and potentiating the infiltration and function of antitumor immune cells. Upon treatment with CDK4/6i, the abundance of tumorinfiltrating immunosuppressive myeloid cells was significantly reduced in breast tumors along with decreased levels of IL-6, IL-10, and IL-23, and these cytokines can depress TH1 response [75]. On the other hand, CDK4/6i enhanced antigen presenting capabilities of macrophages and DCs via upregulating MHC class I and II [76]. Observations disclosed that abemaciclib and palbociclib selectively inhibited the proliferation of Tregs but not CD8 + T cells, which may be attributable to the higher level of RB1 in Tregs [77]. Furthermore, the abundance of the TH1 chemokines CXCL-9 and CXCL-10 in the TIM was also boosted after CDK4/6i treatment, 
inducing the chemotaxis of $\mathrm{T}$ cells towards tumor sites [75]. Similarly, cell cycle arrest caused by CDK4/6i can also elicit the senescence-associated secretory phenotype (SASP), which features an increased richness of chemokines and inflammatory factors released from senescent cells, such as IL-1, IL-6 and IL-8. The SASP is supposed to promote the recruitment of immune cells, including $\mathrm{T}$ cells and macrophages $[130,131]$. Beyond the effects of $\mathrm{CDK} 4 / 6 \mathrm{i}$ in reshaping the $\mathrm{CD} 8+/$ Treg ratio in the TIM, the function of $\mathrm{T}$ cells is directly enhanced by CDK4/6i. Palbociclib was revealed to enhance the nuclear translocation and activity of nuclear factor of activated $\mathrm{T}$ cells (NFAT) in T cells, which gave rise to T cell activation and IL- 2 production mediated by NFAT signaling [75]. It is notable that NFAT governed transcriptional profiling associated with $\mathrm{T}$ cell exhaustion [132], but in the context of immunostimulation induced by CDK4/6i, NFAT mainly evoked the effector gene program. These results strongly support a positive contribution of CDK4/6i to inducing antitumor immunity.

Randomized clinical trials have indicated the efficiacy of ICBs to be related to PD-L1 expression in BC [133, 134]. In $B C$ mouse models administered CDK4/6i, increased levels of PD-1 and CTLA-4 on infiltrating T cells were detected [52]. Wei et al. revealed that PD-L1 expression could be regulated by the cyclin D-CDK4cullin 3- speckle-type POZ protein (SPOP) E3 ligase axis. Cyclin D-CDK4-mediated phosphorylation of SPOP was abrogated by $C D K 4 / 6 \mathrm{i}$, promoting the degradation of SPOP in a proteasome-dependent manner and further reducing cullin 3-SPOP ubiquitin ligase-mediated PD-L1 degradation [135]. CDK4/6i induction of antitumor immunity and immune checkpoint expression in tumor cells and $T$ cells strongly suggest the ability of CDK4/6i to skew "cold" type BC into "hot" tumor, implying their potential of being combined with ICBs [75-77, 135]. Clinical trials of abemaciclib plus pembrolizumab (NCT02779751) as well as the combination of letrozole, palbociclib and pembrolizumab (NCT02778685) for patients with ER $+\mathrm{BC}$ have been carried out (see Table 2) and results are to be expected in the future.

\section{Conclusions}

$\mathrm{HR}+\mathrm{BC}$ has been commonly considered a "cold" tumor. However, accumulating evidence has revealed a greatly increased mutation burden and dynamic changes of TIM in tumors after treatment, especially in advanced HR + BC [136, 137]. The anti-inflammatory function of estrogen is an important factor that shapes the immunosuppressive environment in malignant diseases, including $\mathrm{BC}$. Therefore, most studies have revealed either anti-estrogen treatment with SERMs and SERDs or estrogen deprivation with AIs and GnRHa to boost the function of antitumor immune cells as well as decrease the abundance of immune suppressive cells.

In addition, the influence of small molecule inhibitors targeting the PI3K-AKT-mTOR pathway on the TIM has also been discussed here in our review. Despite the myriad of preclinical studies, controversial conclusions indicate that the real clinical impact of these regimens on TIM remain largely unclear. Recent studies have found that CDK4/6i, which inhibit the cell cycle, can inflame the TIM of HR + BC by repressing Tregs and increasing the infiltration and activation of antitumor immune cells within tumor. These results suggest the ability of CDK4/6i convert "cold" tumors to "hot" tumors, as well as their synergistic effect with ICBs in eradicating $\mathrm{BC}$. However, most preclinical studies have been based on in vitro or mouse models, limiting their generalizability, and the potential therapeutic advantage of combining these agents with standard anti-estrogen treatments must be weighed against the risk of toxicities.

In the era of tumor immunotherapy, experimental strategies are under investigation to improve the efficacy of current anti-estrogen treatments and overcome endocrine therapy resistance. Multiple clinical trials (see Table 2) are currently underway to assess whether the combinations of ICBs with endocrine therapy could be a solution. According to the inclusion criteria, almost of these studies enrolled patients progressed on SERMs, SERDs or AIs, and NCT03280563 is also investigating the effect of atezolizumab plus fulvestrant in patients who have been resistant to CDK4/6 inhibitor, which is acknowledged as the most powerful regimen against $\mathrm{ER}+\mathrm{BC}$. Furthermore, we suggest that samples from previous clinical studies should be reassessed with highthroughput technologies, such as proteomics and singlecell approaches to illuminate the panoramic image of TIM by various treatments, which could be of great help in instructing the therapeutic strategy in $\mathrm{HR}+\mathrm{BC}$.

\footnotetext{
Abbreviations

BC: Breast cancer; ERa: Estrogen receptor alpha; SERMs: Selective estrogen receptor modulators; SERDs: Selective estrogen receptor downregulators; Als:: Aromatase inhibitors: GnRHa: Gonadotropin-releasing hormone antagonists; TIM: Tumor immune microenvironment; NK cells: Natural killer cells; MMP-9: Matrix metalloproteinase-9; PI-9: Protease inhibitor; DCs: Dendritic cells; IDO: Indoleamine 2,3-dioxygenase; Tregs: Regulatory T cells; MDSCs: Marrow-derived immunosuppressive cells; PD-1: Programmed cell death1 receptor; IRF7: Interferon regulatory factor 7; IPSE: Immune polarizing side effects; PD-L1: Programmed death-ligand 1; TNBC: Triple negative breast cancer; ADCC: Antibody-dependent cytotoxicity; ICAM1: Intercellular adhesion molecule-1; NETs: Neutrophil extracellular traps; PMA: Phorbol 12-myristate 13-acetate; TILs: High tumor infiltrating lymphocytes; NET: Neoadjuvant endocrine therapy; PFS: Progression free survival; LAMP-1: Lysosomal associated membrane protein 1; AKT: Protein kinase B; mTOR: The mammalian target of rapamycin; DNMT1: DNA methyl transferase 1; CDK4/6i: Cyclin D/cyclin-dependent kinases 4 and 6 inhibitors; RB: Retinoblastoma protein; HR: Hormone receptor; SASP: Senescenceassociated secretory phenotype; NFAT: Nuclear factor of activated T cells; SPOP: Speckle-type POZ protein
} 


\section{Acknowledgements}

Not applicable.

\section{Authors' contributions}

$\mathrm{HHH}, \mathrm{JZ}$ and HLC drafted the manuscript and prepared the figures and tables. CN and XJ supervised and revised the manuscript. JXL and CZ collected the references and participated in the discussion. All authors read and approved the final manuscript.

\section{Funding}

This work was supported by the Natural Science Foundation of Zhejiang Province (Grant LR19H160001); Zhejiang Provincial Ministry Co-construction Plan (WKJ-ZJ-1716); Zhejiang Public Welfare Technology Research Program (LGF18H160022); Natural Science Foundation of China (Grant 82073151).

\section{Availability of data and materials}

Not applicable.

\section{Ethics approval and consent to participate} Not applicable.

\section{Consent for publication}

Not applicable.

\section{Competing interests}

The authors declare that they have no competing interests.

\section{Author details}

'Department of Breast Surgery, Second Affiliated Hospital Zhejiang University, Zhejiang 310009 Hangzhou, China. ${ }^{2}$ Key Laboratory of Tumour Microenvironment and Immune Therapy of Zhejiang Province, Second Affiliated Hospital Zhejiang University, Zhejiang 310009 Hangzhou, China. ${ }^{3}$ Department of Breast Surgery, Affiliated Hangzhou First People's Hospita Zhejiang University, Zhejiang 310006 Hangzhou, China. ${ }^{4}$ Department of Anatomy School of Medicine, Zhejiang University, Zhejiang 310058 Hangzhou, China. ${ }^{5}$ School of Public Health and West China Fourth Hospital, Sichuan University, Chengdu, Sichuan 610064, China. ${ }^{6}$ Department of Clinical Neuroscience Centre for Molecular Medicine, Karolinska Institute, Stockholm 17176, Sweden.

\section{Received: 29 September 2020 Accepted: 24 November 2020}

\section{Published online: 07 January 2021}

\section{References}

1. Bray F, Ferlay J, Soerjomataram I, Siegel RL, Torre LA, Jemal A. Global cancer statistics 2018: GLOBOCAN estimates of incidence and mortality worldwide for 36 cancers in 185 countries. CA Cancer J Clin. 2018;68(6):394-424.

2. Waks AG, Winer EP. Breast cancer treatment: a review. JAMA. 2019;321(3): 288-300.

3. Zurrida S, Veronesi U. Milestones in breast cancer treatment. Breast J. 2015; 21(1):3-12.

4. Presti D, Quaquarini E. The PI3K/AKT/mTOR and CDK4/6 Pathways in Endocrine Resistant HR+/HER2- Metastatic Breast Cancer: Biological Mechanisms and New Treatments. Cancers (Basel). 2019;11(9):1242.

5. Beck JT, Hortobagyi GN, Campone M, Lebrun F, Deleu I. Rug HSo, et al. Everolimus plus exemestane as first-line therapy in $\mathrm{HR}^{+}, \mathrm{HER} 2^{-}$advanced breast cancer in BOLERO-2. Breast Cancer Res Treat. 2014;43(3):459-67.

6. Fabrice A, Eva C, Gabor R, Mario C, Sibylle L. S RH, et al. Alpelisib for PIK3CAmutated, hormone receptor-positive advanced breast cancer. N Engl J Med. 2019;380(20):1929-40.

7. Jones RH, Casbard A, Carucci M, Cox C, Butler R, Alchami F, et al. Fulvestrant plus capivasertib versus placebo after relapse or progression on an aromatase inhibitor in metastatic, oestrogen receptor-positive breast cancer (FAKTION): a multicentre, randomised, controlled, phase 2 trial. Lancet Oncol. 2020;21(3):345-57.

8. Turner NC, Slamon DJ, Ro J, Bondarenko I, Im SA, Masuda N, et al. Overall Survival with Palbociclib and Fulvestrant in Advanced Breast Cancer. N Engl J Med. 2018;379(20):1926-36

9. Im SA, Lu YS, Bardia A, Harbeck N, Colleoni M, Franke F, et al. Overall Survival with Ribociclib plus Endocrine Therapy in Breast Cancer. N Engl J Med. 2019;381(14):307-16.
10. Tower H, Ruppert M, Britt K. The Immune Microenvironment of Breast Cancer Progression. Cancers (Basel). 2019;11(9):1375.

11. Abrahamsson A, Rodriguez GV, Dabrosin C. Fulvestrant-mediated attenuation of the innate immune response decreases ER+ breast cancer growth in vivo more effectively than tamoxifen. Cancer Res. 2020:canres. 1705.2020.

12. Joffroy CM, Buck MB, Stope MB, Popp SL, Pfizenmaier K, Knabbe C. Antiestrogens Induce Transforming Growth Factor $\beta$-Mediated Immunosuppression in Breast Cancer. Cancer Res. 2010;70(4):1314-22.

13. Wang X, Simpson ER, Brown KA. Aromatase overexpression in dysfunctional adipose tissue links obesity to postmenopausal breast cancer. J Steroid Biochem Mol Biol. 2015;153:35-44.

14. Purohit A, Newman SP, Reed MJ. The role of cytokines in regulating estrogen synthesis: implications for the etiology of breast cancer. Breast Cancer Res. 2002;4(2):65-9.

15. Magnani L, Frige G, Gadaleta RM, Corleone G, Fabris S, Kempe H, et al. Acquired CYP19A1 amplification is an early specific mechanism of aromatase inhibitor resistance in ERa metastatic breast cancer. Nat Genet. 2017:49(3):444-50.

16. Kovats $\mathrm{S}$. Estrogen receptors regulate innate immune cells and signaling pathways. Cell Immunol. 2015;294(2):63-9.

17. Choi J, Gyamfi J, Jang H, Koo JS. The role of tumor-associated macrophage in breast cancer biology. Histol Histopathol. 2018;33(2):133-45.

18. Segovia-Mendoza M, Morales-Montor J. Immune Tumor Microenvironment in Breast Cancer and the Participation of Estrogen and Its Receptors in Cancer Physiopathology. Front Immunol. 2019;10:348.

19. Vegeto E, Ghisletti S, Meda C, Etteri S, Belcredito S, Maggi A. Regulation of the lipopolysaccharide signal transduction pathway by 17 betaestradiol in macrophage cells. J Steroid Biochem Mol Biol. 2004;91(1-2): 59-66.

20. Kramer PR. S F Kramer, Guan G. 17 beta-estradiol regulates cytokine release through modulation of CD16 expression in monocytes and monocytederived macrophages. Arthritis Rheum. 2004;50(6):1967-75.

21. Rogers A, Eastell R. The effect of 17beta-estradiol on production of cytokines in cultures of peripheral blood. Bone. 2001;29(1):30-4.

22. Nilsson N, Carlsten H. Estrogen induces suppression of natural killer cell cytotoxicity and augmentation of polyclonal B cell activation. Cell Immunol. 1994;158(1):131-9.

23. Jiang X, Ellison S, Alarid E, Shapiro DJ. Interplay between the levels of estrogen and estrogen receptor controls the level of the granzyme inhibitor, proteinase inhibitor 9 and susceptibility to immune surveillance by natural killer cells. Oncogene. 2007;26(28):4106-14.

24. Laffont S, Seillet C, Guéry JC. Estrogen receptor-dependent regulation of dendritic cell development and function. Front Immunol. 2017;8:108.

25. Liu HY, Buenafe AC, Matejuk A, Ito A, Zamora A, Dwyer J, et al. Estrogen inhibition of EAE involves effects on dendritic cell function. J Neurosci Res. 2002;70:238-48

26. Xiao BG, Liu X, Link H. Antigen-specific T cell functions are suppressed over the estrogen-dendritic cell-indoleamine 2, 3-dioxygenase axis. Steroids. 2004;69(10):653-9.

27. McMurray RW, Ndebele K, Hardy K, Jenkins JK. 17- $\beta$-estradiol suppresses IL2 and IL-2 receptor. Cytokine. 2001;14(6):324-33.

28. Polanczyk MJ, Carson BD, Subramanian S, Afentoulis M, Vandenbark AA, Ziegler SF, et al. Cutting edge: estrogen drives expansion of the CD4+ CD25+ regulatory T cell compartment. J Immunol. 2004;173(4):2227-30.

29. Svoronos N, Perales-Puchalt A, Allegrezza MJ, Rutkowski MR, Payne KK, Tesone AJ, et al. Tumor cell-independent estrogen signaling drives disease progression through mobilization of myeloid-derived suppressor cells. Cancer Discov. 2017;7(1):72-85.

30. Polanczyk MJ, Hopke C, Vandenbark AA, Offner H. Treg suppressive activity involves estrogen-dependent expression of programmed death-1 (PD-1). Int Immunol. 2007;19(3):337-43

31. Chung HH, Or YZ, Shrestha S, Loh JT, Lim CL, Ong Z, et al. Estrogen reprograms the activity of neutrophils to foster protumoral microenvironment during mammary involution. Sci Rep. 2017;7:46485.

32. Zhang W, Shen Y, Huang H, Pan S, Jiang J, Chen W, et al. A Rosetta Stone for Breast Cancer: Prognostic Value and Dynamic Regulation of Neutrophil in Tumor Microenvironment. Front Immunol. 2020;11:1779.

33. Traboulsi T, Ezzy ME, Gleason JL, Mader S. Antiestrogens: structure-activity relationships and use in breast cancer treatment. J Mol Endocrinol. 2017; 58(1):R15-31. 
34. Behjati S, Frank M. The effects of tamoxifen on immunity. Curr Med Chem. 2009:16(24):3076-80

35. Komi J, Lassila O. Antioestrogens enhance tumour necrosis factor receptor 2 (TNF-R2) expression and TNF-R2-mediated proliferation in activated T cells. Scand J Immunol. 1998;48(3):254-60.

36. Richards JO, Albers AJ, Smith TS, Tjoe JA. NK cell-mediated antibodydependent cellular cytotoxicity is enhanced by tamoxifen in HER2/neu nonamplified, but not HER2/neu-amplified, breast cancer cells. Cancer Immunol Immunother. 2016;65(11):1325-35.

37. Nalbandian G, Paharkova-Vatchkova V, Mao A, Nale S, Kovats S. The selective estrogen receptor modulators, tamoxifen and raloxifene, impair dendritic cell differentiation and activation. J Immunol. 2005;175(4):2666-75.

38. Corriden R, Hollands A, Olson J, Derieux J, Lopez J, Chang JT, et al. Tamoxifen augments the innate immune function of neutrophils through modulation of intracellular ceramide. Nat Commun. 2015;6(1):1-8.

39. Flores R, Döhrmann S, Schaal C, Hakkim A, Nizet V, Corriden R. The selective estrogen receptor modulator raloxifene inhibits neutrophil extracellular trap formation. Front Immunol. 2016;7:566.

40. Márquez-Garbán DC, Deng G, Comin-Anduix B, Garcia AJ, Xing Y, Chen H-W, et al. Antiestrogens in combination with immune checkpoint inhibitors in breast cancer immunotherapy. J Steroid Biochem Mol Biol. 2019:193:105415.

41. Chan MS, Wang L, Felizola SJ, Ueno T, Toi M, Loo W, et al. Changes of tumor infiltrating lymphocyte subtypes before and after neoadjuvant endocrine therapy in estrogen receptor-positive breast cancer patients-an immunohistochemical study of $\mathrm{Cd} 8+$ and FOXp3+ using double immunostaining with correlation to the pathobiological response of the patients. Int J Biol Markers. 2012;27(4):295-304.

42. Jingxuan W, Qingyuan Z, Shi J, Meiyan F, Xinmei K, Shu Z, et al. Immoderate inhibition of estrogen by anastrozole enhances the severity of experimental polyarthritis. Exp Gerontol. 2009;44(6-7):398-405.

43. Aggelakopoulou M, Kourepini E, Paschalidis I, Panoutsakopoulou V. ERß in CD4+ T Cells is Crucial for Ligand-Mediated Suppression of Central Nervous System Autoimmunity. J Immunol. 2016;196(12):4947-56.

44. Rao Q, Chen Y, Yeh C-R, Ding J, Li L, Chang C, et al. Recruited mast cells in the tumor microenvironment enhance bladder cancer metastasis via modulation of ERB/CCL2/CCR2 EMT/MMP9 signals. Oncotarget. 2016;7(7): 7842-55.

45. Sung N, García MDS, Dambaeva S, Beaman KD, Gilman-Sachs A, Kwak-Kim J. Gonadotropin-releasing hormone analogues lead to pro-inflammatory changes in T lymphocytes. Am J Reprod Immunol. 2016;76(1):50-8.

46. Xie S, Chen M, Yan B, He X, Chen X, Li D. Identification of a role for the PISK/AKT/mTOR signaling pathway in innate immune cells. PLoS One. 2014; 9(4):e94496.

47. Abu-Eid R, Samara RN, Ozbun L, Abdalla MY, Berzofsky JA, Friedman KM, et al. Selective inhibition of regulatory T cells by targeting the PI3K-Akt pathway. Cancer Immunol Res. 2014;2(11):1080-9.

48. Blanco B, Herrero-Sánchez C, Rodríguez-Serrano C, Sánchez-Barba M, del Cañizo MC. Comparative effect of two pan-class I PI3K inhibitors used as anticancer drugs on human T cell function. Int Immunopharmacol. 2015; 28(1):675-85.

49. Sai J, Owens P, Novitskiy SV, Hawkins OE, Vilgelm AE, Yang J, et al. PI3K inhibition reduces mammary tumor growth and facilitates antitumor immunity and anti-PD1 responses. Clin Cancer Res. 2017;23(13):3371-84.

50. Choi J-H, Kim KH, Roh K-H, Jung H, Lee A, Lee J-Y, et al. A PI3K p110aselective inhibitor enhances the efficacy of anti-HER2/neu antibody therapy against breast cancer in mice. Oncoimmunology. 2018;7(5):e1421890.

51. Aragoneses-Fenoll L, Ojeda G, Montes-Casado M, Acosta-Ampudia Y, Dianzani U, Portolés P, et al. T-Cell-Specific Loss of the PI-3-Kinase p110a Catalytic Subunit Results in Enhanced Cytokine Production and Antitumor Response. Front Immunol. 2018;9:332.

52. Teo ZL, Versaci S, Dushyanthen $\mathrm{S}$, Caramia F, Savas P, Mintoff CP, et al. Combined CDK4/6 and PI3Ka inhibition is synergistic and immunogenic in triple-negative breast cancer. Cancer Res. 2017;77(22):6340-52.

53. Leverrier Y, Okkenhaug K, Sawyer C, Bilancio A, Vanhaesebroeck B, Ridley AJ. Class I phosphoinositide 3-kinase p110beta is required for apoptotic cell and Fcgamma receptor-mediated phagocytosis by macrophages. J Biol Chem. 2003;278(40):38437-42.

54. Houslay DM, Anderson KE, Chessa T, Kulkarni S, Fritsch R, Downward J, et al. Coincident signals from GPCRs and receptor tyrosine kinases are uniquely transduced by PI3Kß in myeloid cells. Sci Signal. 2016;9(441):ra82.
55. Schmid MC, Avraamides CJ, Dippold HC, Franco I, Foubert P, Ellies LG, et al. Receptor Tyrosine Kinases and TLR/LL1Rs Unexpectedly Activate Myeloid Cell PI3Kg, A Single Convergent Point Promoting Tumor Inflammation and Progression. Cancer Cell. 2011;19(6):715-27.

56. Kaneda MM, Messer KS, Ralainirina N, Li H, Leem CJ, Gorjestani S, et al. PI3KY is a molecular switch that controls immune suppression. Nature. 2016; 539(7629):437-42

57. De Henau O, Rausch M, Winkler D, Campesato LF, Liu C, Cymerman DH, et al. Overcoming resistance to checkpoint blockade therapy by targeting PI3KY in myeloid cells. Nature. 2016;539(7629):443-7.

58. Goulielmaki E, Bermudez-Brito M, Andreou M, Tzenaki N, Tzardi M, Ed B, et al. Pharmacological inactivation of the PI3K p1108 prevents breast tumour progression by targeting cancer cells and macrophages. Cell Death Dis. 2018;9(6):678.

59. Ali K, Soond DR, Pineiro R, Hagemann T, Pearce W, Lim EL, et al. Inactivation of PI(3)K p1 $10 \delta$ breaks regulatory T-cell-mediated immune tolerance to cancer. Nature. 2014;510(7505):407-11.

60. Soond DR, Bjørgo E, Moltu K, Dale VQ, Patton DT, Torgersen KM, et al. PI3K p110delta regulates T-cell cytokine production during primary and secondary immune responses in mice and humans. Blood. 2010;115(11): 2203-13.

61. Chiu H, Mallya S, Nguyen P, Mai A, Jackson LV, Winkler DG, et al. The Selective Phosphoinoside-3-Kinase p1108 Inhibitor IPI-3063 Potently Suppresses B Cell Survival, Proliferation, and Differentiation. Front Immunol. 2017:8:747.

62. Gato-Cañas M. Morentin XMd, Blanco-Luquin I, Fernandez-lrigoyen J, Zudaire I, Liechtenstein T, et al. A core of kinase-regulated interactomes defines the neoplastic MDSC lineage. Oncotarget. 2015;6(29):27160-75.

63. Arranz A, Doxaki C, Vergadi E, Torre YM, Vaporidi K, Lagoudaki ED, et al. Akt1 and Akt2 protein kinases differentially contribute to macrophage polarization. Proc Natl Acad Sci U S A. 2012;109(24):9517-22.

64. Nandagopal N, Ali AK, Komal AK, Lee S-H. The Critical Role of IL-15-PI3KmTOR Pathway in Natural Killer Cell Effector Functions. Front Immunol. 2014;5:187.

65. Marçais A, Cherfils-Vicini J, Viant C, Degouve S, Viel S, Fenis A, et al. The metabolic checkpoint kinase mTOR is essential for interleukin-15 signaling during NK cell development and activation. Nat Immunol. 2014;15(8):74957.

66. Haidinger M, Poglitsch M, Geyeregger R, Kasturi S, Zeyda M, Zlabinger GJ, et al. A versatile role of mammalian target of rapamycin in human dendritic cell function and differentiation. J Immunol. 2010;185(7):3919-31.

67. Zheng Y, Delgoffe GM, Meyer CF, Chan W, Powell JD. Anergic T cells are metabolically anergic. J Immunol. 2009;183(10):6095-101.

68. Pollizzi KN, Patel CH, Sun I-H, Oh M-H, Waickman AT, Wen J, et al. mTORC1 and mTORC2 selectively regulate CD8 ${ }^{+} \mathrm{T}$ cell differentiation. J Clin Invest. 2015;125(5):2090-108.

69. Chaoul N, Fayolle C, Desrues B, Oberkampf M, Tang A, Ladant D, et al. Rapamycin Impairs Antitumor CD8+ T-cell Responses and Vaccine-Induced Tumor Eradication. Cancer Res. 2015;75(16):3279-91.

70. Daniel C, Wennhold K, Kim H-J, Boehmer H. Enhancement of antigenspecific Treg vaccination in vivo. Proc Natl Acad Sci U S A. 2010;107(37): 16246-51.

71. Cao G, Wang Q, Li G, Meng Z, Liu H, Tong J, et al. mTOR inhibition potentiates cytotoxicity of $V_{\gamma} 4 \gamma \delta$ T cells via up-regulating NKG2D and TNFa. J Leukoc Biol. 2016;100(5):1181-9.

72. Li H, Pauza CD. Rapamycin increases the yield and effector function of human $\gamma \delta$ T cells stimulated in vitro. Cancer Immunol Immunother. 2011; 60(3):361-70.

73. Procaccini C, Rosa VD, Galgani M, Abanni L, Cali G, Porcellini A, et al. An oscillatory switch in mTOR kinase activity sets regulatory $\mathrm{T}$ cell responsiveness. Immunity. 2010;33(6):929-41.

74. Rosa VD, Galgani M, Porcellini A, Colamatteo A, Santopaolo M, Zuchegna C, et al. Glycolysis controls the induction of human regulatory $T$ cells by modulating the expression of FOXP3 exon 2 splicing variants. Nat Immunol. 2015;16(11):1174-84

75. Deng J, Wang ES, Jenkins RW, Li S, Dries R, Yates K, et al. CDK4/6 inhibition augments antitumor immunity by enhancing T-cell activation. Cancer Discov. 2018;8(2):216-33.

76. Schaer DA, Beckmann RP, Dempsey JA, Huber L, Forest A, Amaladas N, et al. The CDK4/6 inhibitor abemaciclib induces a T cell inflamed tumor 
microenvironment and enhances the efficacy of PD-L1 checkpoint blockade. Cell Rep. 2018:22(11):2978-94.

77. Goel S, DeCristo MJ, Watt AC, BrinJones H, Sceneay J, Li BB, et al. CDK4/6 inhibition triggers anti-tumour immunity. Nature. 2017:548(7668):471-5.

78. Dabydeen SA, Kang K, Díaz-Cruz ES, Alamri A, Axelrod ML, Bouker KB, et al. Comparison of tamoxifen and letrozole response in mammary preneoplasia of ER and aromatase overexpressing mice defines an immune-associated gene signature linked to tamoxifen resistance. Carcinogenesis. 2015;36(1): 122-32

79. Jr BFB, Dehghani B, Foster S, Kurniawan A, Lopez FJ, Sherman LS. Treatment with selective estrogen receptor modulators regulates myelin specific T-cells and suppresses experimental autoimmune encephalomyelitis. Glia. 2009; 57(7):777-90.

80. Li B, Li Y, Wang XY, Yan ZQ, Liu H, Liu GR, et al. Profile of differentially expressed intratumoral cytokines to predict the immune-polarizing side effects of tamoxifen in breast cancer treatment. Am J Cancer Res. 2015;5(2): 726.

81. Huhn D, Martí-Rodrigo P, Mouron S, Hansel C, Tschapalda K, Haggblad M, et al. Estrogen deprivation triggers an immunosuppressive phenotype in breast cancer cells. bioRxiv. 2019:715136.

82. Rugo HS, Delord J-P, Im S-A, Ott PA, Piha-Paul SA, Bedard PL, et al. Safety and antitumor activity of pembrolizumab in patients with estrogen receptor-positive/human epidermal growth factor receptor 2-negative advanced breast cancer. Clin Cancer Res. 2018;24(12):2804-11.

83. Nanda R, Chow LQ, Dees EC, Berger R, Gupta S, Geva R, et al. Pembrolizumab in patients with advanced triple-negative breast cancer: phase Ib KEYNOTE-012 study. J Clin Oncol. 2016;34(21):2460-7.

84. Jaini R, Loya MG, Eng C. Immunotherapeutic target expression on breast tumors can be amplified by hormone receptor antagonism: a novel strategy for enhancing efficacy of targeted immunotherapy. Oncotarget. 2017;8(20): 32536.

85. Komi J, Lassila O. Toremifene increases the expression of intercellular adhesion molecule-1 (ICAM-1) on MCF-7 breast cancer cells and Jurkat cells. Scand J Immunol. 2000;51(1):73-8.

86. Mor G, Kohen F, Garcia-Velasco J, Nilsen J, Brown W, Song J, et al. Regulation of fas ligand expression in breast cancer cells by estrogen: functional differences between estradiol and tamoxifen. J Steroid Biochem Mol Biol. 2000;73(5):185-94

87. Svensson S, Abrahamsson A, Rodriguez GV, Olsson A-K, Jensen L, Cao Y, et al. CCL2 and CCL5 are novel therapeutic targets for estrogen-dependent breast cancer. Clin Cancer Res. 2015;21(16):3794-805.

88. Cuzick JSI, Cawthorn S. Tamoxifen for prevention of breast cancer: extended long-term follow-up of the IBIS-I breast cancer prevention trial. Lancet Oncol. 2015;16(1):67-75.

89. Schild-Hay LJ, Leil TA, Divi RL, Olivero OA, Weston A, Poirier MC. Tamoxifen Induces Expression of Immune Response-Related Genes in Cultured Normal Human Mammary Epithelial Cells. Cancer Res. 2009;69(3):1150-5.

90. Albrengues J, Shields MA, Ng D, Park CG, Ambrico A, Poindexter ME, et al. Neutrophil extracellular traps produced during inflammation awaken dormant cancer cells in mice. Science. 2018;361(6409):eaao4227.

91. Simpson ER. Sources of estrogen and their importance. J Steroid Biochem Mol Biol. 2003;86(3-5):225-30.

92. De Placido S, Gallo C, De Laurentiis M, Bisagni G, Arpino G, Sarobba MG, et al. Adjuvant anastrozole versus exemestane versus letrozole, upfront or after 2 years of tamoxifen, in endocrine-sensitive breast cancer (FATA-GIM3): a randomised, phase 3 trial. Lancet Oncol. 2018;19(4):474-85.

93. Straub RH. The complex role of estrogens in inflammation. Endocr Rev. 2007;28(5):521-74

94. Braun DP, Crist KA, Shaheen F, Staren ED, Andrews S, Parker J. Aromatase inhibitors increase the sensitivity of human tumor cells to monocytemediated, antibody-dependent cellular cytotoxicity. Am J Surg. 2005;190(4): 570-1.

95. Generali D, Bates G, Berruti A, Brizzi MP, Campo L, Bonardi S, et al. Immunomodulation of FOXP3+ regulatory T cells by the aromatase inhibitor letrozole in breast cancer patients. Clin Cancer Res. 2009;15(3): 1046-51.

96. Guo D, Liu X, Zeng C, Cheng L, Song G, Hou X, et al. Estrogen receptor $\beta$ activation ameliorates DSS-induced chronic colitis by inhibiting inflammation and promoting Treg differentiation. Int Immunopharmacol. 2019;77:105971.
97. Aponte-López A, Fuentes-Pananá EM, Cortes-Muñoz D, Muñoz-Cruz S. Mast Cell, the Neglected Member of the Tumor Microenvironment: Role in Breast Cancer. J Immunol Res. 2018;2018:2584243.

98. Bense RD, Sotiriou C, Piccart-Gebhart MJ, Haanen JB, van Vugt MA, de Vries $E G$, et al. Relevance of tumor-infiltrating immune cell composition and functionality for disease outcome in breast cancer. J Natl Cancer Inst. 2016; 109(1):djw192.

99. Mello-Grand M, Singh V, Ghimenti C, Scatolini M, Regolo L, Grosso E, et al. Gene expression profiling and prediction of response to hormonal neoadjuvant treatment with anastrozole in surgically resectable breast cancer. Breast Cancer Res Treat. 2010;121(2):399-411.

100. Dunbier AK, Ghazoui Z, Anderson H, Salter J, Nerurkar A, Osin P, et al. Molecular profiling of aromatase inhibitor-treated postmenopausal breast tumors identifies immune-related correlates of resistance. Clin Cancer Res. 2013;19(10):2775-86

101. Gao Q, Patani N, Dunbier AK, Ghazoui Z, Zvelebil M, Martin L-A, et al. Effect of aromatase inhibition on functional gene modules in estrogen receptorpositive breast cancer and their relationship with antiproliferative response. Clin Cancer Res. 2014;20(9):2485-94.

102. Liang X, Briaux A, Becette V, Benoist C, Boulai A, Chemlali W, et al. Molecular profiling of hormone receptor-positive, HER2-negative breast cancers from patients treated with neoadjuvant endocrine therapy in the CARMINA 02 trial (UCBG-0609). J Hematol Oncol. 2018;11(1):124.

103. Skriver SK, Jensen M-B, Knoop AS, Ejlertsen B, Laenkholm A-V. Tumourinfiltrating lymphocytes and response to neoadjuvant letrozole in patients with early oestrogen receptor-positive breast cancer: analysis from a nationwide phase II DBCG trial. Breast Cancer Res. 2020;22(1):46.

104. Stemke-Hale K, Gonzalez-Angulo AM, Lluch A, Neve RM, Kuo W-L, Davies M, et al. An integrative genomic and proteomic analysis of PIK3CA, PTEN, and AKT mutations in breast cancer. Cancer Res. 2008;68(15):6084-91.

105. Baselga J, Im S-A, Iwata H, Cortés J, Laurentiis MD, Jiang Z, et al. Buparlisib plus fulvestrant versus placebo plus fulvestrant in postmenopausal, hormone receptor-positive, HER2-negative, advanced breast cancer (BELLE2): a randomised, double-blind, placebo-controlled, phase 3 trial. Lancet Oncol. 2017;20(2):904-16.

106. Krop IE, Mayer IA, Ganju V, Dickler M, Johnston S, Morales S, et al. Pictilisib for oestrogen receptor-positive, aromatase inhibitorresistant, advanced or metastatic breast cancer (FERGI): A randomised, double-blind, placebocontrolled, phase 2 trial. Lancet Oncol. 2016;17(6):811-21.

107. Juric D, Janku F, Rodón J, Burris HA, Mayer IA, Schuler M, et al. Alpelisib Plus Fulvestrant in PIK3CA-Altered and PIK3CA-Wild-Type Estrogen ReceptorPositive Advanced Breast Cancer: A Phase 1b Clinical Trial. JAMA Oncol. 2019;5(2):e184475.

108. Dickler MN, Saura C, Richards DA, Krop IE, Cervantes A, Bedard PL, et al. Phase II Study of Taselisib (GDC-0032) in Combination with Fulvestrant in Patients with HER2-Negative, Hormone Receptor-Positive Advanced Breast Cancer. Clin Cancer Res. 2018;24(18):4380-7.

109. Kok K, Geering B, Vanhaesebroeck B. Regulation of phosphoinositide 3kinase expression in health and disease. Trends Biochem Sci. 2009;34(3): 115-27.

110. Blanco B, Herrero-Sánchez MC, Rodríguez-Serrano C, Sánchez-Barba M, Cañizo MCD. Profound blockade of T cell activation requires concomitant inhibition of different class I PI3K isoforms. Immunol Res. 2015;62(2):175-88.

111. Crane C, Panner A, Murray J, Wilson S, Xu H, Chen L, et al. PI (3) kinase is associated with a mechanism of immunoresistance in breast and prostate cancer. Oncogene. 2009;28(2):306-12.

112. Carvalho S, Milanezi F, Costa JL, Amendoeira I, Schmitt F. PIKing the right isoform: the emergent role of the p1 10 $\beta$ subunit in breast cancer. Virchows Archiv An Int J Pathol. 2010;456(3):235-43.

113. Crowder RJ, Phommaly C, Tao Y, Hoog J, Luo J, Perou CM, et al. PIK3CA and PIK3CB inhibition produce synthetic lethality when combined with estrogen deprivation in estrogen receptor positive breast cancer. Cancer Res. 2009; 69(9):3955-62.

114. Hosford SR, Dillon LM, Bouley SJ, Rosati R, Yang W, Chen VS, et al. Combined Inhibition of Both p110a and p110 $\beta$ Isoforms of Phosphatidylinositol 3-Kinase Is Required for Sustained Therapeutic Effect in PTEN-Deficient, ER+ Breast Cancer. Clin Cancer Res. 2017;23(11):2795-805.

115. Araki K, Miyoshi Y. Mechanism of resistance to endocrine therapy in breast cancer: the important role of PI3K/Akt/mTOR in estrogen receptor-positive, HER2-negative breast cancer. Breast Cancer. 2018;25(4):392-401. 
116. Zhang B, Ma Y, Guo H, Sun B, Niu R, Ying G, et al. Akt2 is required for macrophage chemotaxis. Eur J Immunol. 2009;39(3):894-901.

117. Wang J, Wan W, Sun R, Liu Y, Sun X, Ma D, et al. Reduction of Akt2 expression inhibits chemotaxis signal transduction in human breast cancer cells. Cell Signal. 2008;20(6):1025-34.

118. O'Shaughnessy J, Beck JT, Royce M. Everolimus-based combination therapies for HR+, HER2 - metastatic breast cancer. Cancer Treat Rev. 2018; 69:204-14.

119. Zeng H. mTOR signaling in immune cells and its implications for cancer immunotherapy. Cancer Lett. 2017;408:182-9.

120. Powell JD, Lerner CG, Schwartz RH. Inhibition of cell cycle progression by rapamycin induces $T$ cell clonal anergy even in the presence of costimulation. J Immunol. 1999;162(5):2775-84.

121. Mercalli A, Calavita I, Dugnani E, Citro A, Cantarelli E, Nano R, et al. Rapamycin unbalances the polarization of human macrophages to M1. Immunology. 2013;140(2):179-90.

122. Chen W, Ma T, Shen X-n, Xia X-f, Xu G-d, Bai X-I, et al. Macrophage-induced tumor angiogenesis is regulated by the TSC2-mTOR pathway. Cancer Res. 2012;72(6):1363-72.

123. Deng Y, Yang J, Luo F, Qian J, Liu R, Zhang D, et al. mTOR-mediated glycolysis contributes to the enhanced suppressive function of murine tumor-infiltrating monocytic myeloid-derived suppressor cells. Cancer Immunol Immunother. 2018;67(9):1355-64.

124. Wu T, Zhao Y, Wang H, Shao L, Wang R, Lu J, et al. mTOR masters monocytic myeloid-derived suppressor cells in mice with allografts or tumors. Sci Rep. 2016;6:20250

125. Amiel E, Everts B, Freitas TC, King IL, Curtis JD, Pearce EL, et al. Inhibition of mechanistic target of rapamycin promotes dendritic cell activation and enhances therapeutic autologous vaccination in mice. J Immunol. 2012; 189(5):2151-8.

126. Ni C, Fang Q-Q, Chen W-Z, Jiang J-X, Jiang Z, Ye J, et al. Breast cancer-

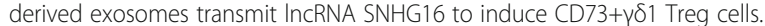
Signal Transduct Target Ther. 2020;5(1):41.

127. Cristofanilli M, Turner NC, Bondarenko I, Ro J, Im S-A, Masuda N, et al. Fulvestrant plus palbociclib versus fulvestrant plus placebo for treatment of hormone-receptor-positive, HER2-negative metastatic breast cancer that progressed on previous endocrine therapy (PALOMA-3): final analysis of the multicentre, double-blind, phase 3 randomised controlled trial17. Lancet Oncol. 2016;17(4):425-39.

128. Tripathy D, Im S-A, Colleoni M, Franke F, Bardia A, Harbeck N, et al. Ribociclib plus endocrine therapy for premenopausal women with hormone-receptor-positive, advanced breast cancer (MONALEESA-7): a randomised phase 3 trial. Lancet Oncol. 2018;19(7):904-15.

129. Sledge GW Jr, Toi M, Neven P, Sohn J, Inoue K, Pivot X, et al. The Effect of Abemaciclib Plus Fulvestrant on Overall Survival in Hormone ReceptorPositive, ERBB2-Negative Breast Cancer That Progressed on Endocrine Therapy-MONARCH 2: A Randomized Clinical Trial. JAMA Oncol. 2019;6(1): $116-24$

130. Watanabe S, Kawamoto S, Ohtani N, Hara E. Impact of senescenceassociated secretory phenotype and its potential as a therapeutic target for senescence-associated diseases. Cancer Sci. 2017:108(4):563-9.

131. Lau L, David G. Pro- and anti-tumorigenic functions of the senescenceassociated secretory phenotype. Expert Opin Ther Targets. 2019;23(12): 1041-51.

132. Martinez GJ, Pereira RM, Äijö T, Kim EY, Marangoni F, Pipkin ME, et al. The transcription factor NFAT promotes exhaustion of activated $\mathrm{CD} 8^{+} \mathrm{T}$ cells. Immunity. 2015;42(2):265-78.

133. Schmid P, Cortes J, Pusztai L, McArthur H, Kümmel S, Bergh J, et al. Pembrolizumab for Early Triple-Negative Breast Cancer. N Engl J Med. 2020; 382(9):810-21.

134. Schmid P, Adams S, Rugo HS, Schneeweiss A, Barrios $\mathrm{CH}$, Iwata $\mathrm{H}$, et al. IMpassion130: updated overall survival (OS) from a global, randomized, double-blind, placebo-controlled, Phase III study of atezolizumab (atezo)+ nab-paclitaxel (nP) in previously untreated locally advanced or metastatic triple-negative breast cancer (mTNBC). J Clin Oncol. 2019;37(15):suppl.

135. Zhang J, Bu X, Wang H, Zhu Y, Geng Y, Nihira NT, et al. Cyclin D-CDK4 kinase destabilizes PD-L1 via cullin 3-SPOP to control cancer immune surveillance. Nature. 2018;553(7686):91-5.

136. Hu ZY, Xie N, Tian C, Yang X, Liu L, Li J, et al. Identifying Circulating Tumor DNA Mutation Profiles in Metastatic Breast Cancer Patients with Multiline Resistance. EBioMedicine. 2018;32:111-8.
137. Waks AG, Stover DG, Guerriero JL, Dillon D, Barry WT, Gjini E, et al. The Immune Microenvironment in Hormone Receptor-Positive Breast Cancer Before and After Preoperative Chemotherapy. Clin Cancer Res. 2019;25(15): $4644-55$.

\section{Publisher's Note}

Springer Nature remains neutral with regard to jurisdictional claims in published maps and institutional affiliations.

\section{Ready to submit your research? Choose BMC and benefit from:}

- fast, convenient online submission

- thorough peer review by experienced researchers in your field

- rapid publication on acceptance

- support for research data, including large and complex data types

- gold Open Access which fosters wider collaboration and increased citations

- maximum visibility for your research: over $100 \mathrm{M}$ website views per year

At $\mathrm{BMC}$, research is always in progress.

Learn more biomedcentral.com/submissions 